\title{
Diving Behavior of Female Loggerhead Turtles (Caretta caretta) During Their Internesting Interval and an Evaluation of the Risk of Boat Strikes
}

\author{
By \\ Jacob Matthew Sobin \\ Dr. Scott Eckert, Advisor \\ December 2008
}

Masters project submitted in partial fulfillment of the requirements for the Master of Environmental Management degree in the Nicholas School of the Environment of

Duke University

2008 


\begin{abstract}
New advantages in science and technology, such as time depth recorders (TDRs), have allowed researchers to study the dive behavior of sea turtles in their natural habitats. Observing dive behavior of internesting turtles has provided significant evidence on how to protect nesting turtles from human interactions. One source of anthropogenic mortality on marine turtles is boat strikes. Trend data from the Florida Sea Turtle Stranding Network demonstrate that the annual proportions of boat-strike related mortality is increasing. Since 1980 boat strike injuries have tripled in Florida. This study, near Casey Key Beach in southwest Florida, examined the internesting dive behavior of loggerhead sea turtles using time-depth-recorders; National Geographic Crittercams ${ }^{\mathrm{tm}}$, and satellitelinked location data to evaluate the risk of boat impacts based on the resulting dive data. When combined with 4 years of satellite telemetry data gathered prior to this study I revealed that loggerhead turtles are most vulnerable to boat strikes between 8 a.m. -12 p.m. on the day following a nesting or false crawl event and on the night before returning to the beach to nest. Potential mitigation measures, such as spatial and temporal boat restrictions, are reviewed by this study.
\end{abstract}




\section{Table of Contents}

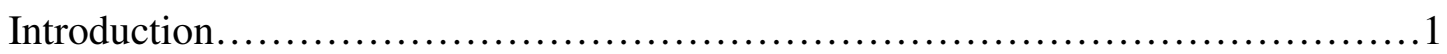

Marine Policy and Law.............................................. 5

Methods and Material................................................... 7

Results.............................................................. 13

Discussion............................................................ 21

Acknowledgements.....................................................

Sources and Literature Cited.............................................29

Appendix

Calculations.......................................................

Tables..........................................................

Figures........................................................... 


\section{Introduction}

The loggerhead sea turtle (Caretta caretta) is classified under the U.S. Endangered Species Act (ESA) of 1973 as Threatened (www.nmfs.noaa.gov). The term Threatened is defined in the ESA of 1973 as a species that is expected to become endangered in the future. This classification provides protection for the species within U.S. waters by prohibiting the direct take or killing, and regulates incidental mortality attributed to anthropogenic causes. Globally, the loggerhead is classified as Endangered by the World Conservation Union (IUCN) as described by their "Red List" (www.iucnredlist.org). Further the loggerhead is listed under Appendix 1 of the Convention in Trade of Endangered Species of Wild Fauna and Flora, or CITES, which prohibits international trade in products derived from listed species between signatory nations (www.cites.org). The inclusion of loggerhead sea turtles on these domestic and international classifications attests to the species status as in danger of extinction.

A long-term monitoring program coordinated by the Florida Fish and Wildlife Conservation Commission (FWC), reports that loggerhead nesting in the state of Florida has declined. Based on nesting data collected at 27 Florida index beaches, nesting by loggerheads has declined during the last 18 years (1989-2007) with a 50\% drop between 1998 and 2007 (Fig. 1) (www.myfwc.com).

One source of anthropogenic mortality on marine turtles is boat strikes (Loggerhead/Green Recovery Team, 1991). In Florida between 1980 - 2005, over 4,000 ( 500 live; $~ 3500$ dead) sea turtle strandings were documented with propeller wounds which represents $30 \%$ of all sea turtle strandings for that State (Singel et al., 2007). Furthermore trend data from the Florida Sea Turtle Stranding Network demonstrate that 
the annual proportions of boat-strike related mortality is increasing (Fig. 2). Since 1980 boat strike injuries have tripled in Florida (Singel et al., 2007). Loggerhead sea turtles account for $12 \%$ of all standings among sea turtles in both the Atlantic and Pacific Ocean (Singel et al., 2007), and while it is not clear that loggerheads are more or less prone to boat strikes than other species of sea turtle (Heithaus et al., 2002), they live in nearshore coastal waters (Norem, 2006) where encounters with boats are likely.

This project seeks to evaluate when and where loggerheads could be subject to boat strikes by monitoring their presence in near-surface waters, and suggest possible mitigation measures to reduce boat strike probability. My approach was to measure diving behavior (depth and duration) of loggerheads during the time between nesting events and to use that information to determine what proportion of time is spent within depths subject to impact by boat hulls and propellers. Like all sea turtles, loggerheads must surface to breathe and it is during these surfacing episodes near shore that they are exposed to vessel collisions. I also used satellite telemetry data to evaluate where turtles reside after nesting to assess geographic location where boat injuries have a higher probability.

Ninety-eight percent of boats registered in the state of Florida are less than or equal to 12.2 meters (40 ft) in length (Rommel et al., 2007). To understand why turtles are struck by boat hulls and propellers requires knowledge of boat draft. The definition of boat draft is the depth of water a boat occupies at any given time (www.en.mimi.hu). The draft depends on the length of the boat, so boats with increased draft sit lower in the water (Mellor, 1992). My project's goal was to explain the correlation between boat draft and risk of boat strikes on turtles. 
New advances in science and technology, such as data loggers that can monitor dive depths and durations (e.g. time-depth-recorder or TDRs), have allowed researchers to better understand the behavior of sea turtles in their natural habitats (Eckert et al. 1986, Eckert 2002, Southwood et al. 1999). With loggerheads such methods have been used to study diving and surfacing behavior (Houghton et al., 2002), with most directed toward studying female turtles during the period between nesting events in a single season (Houghton et al., 2002; Hays et al.,2002; Sato et al.,1994; Sato et al.,1995; Webster and Cook, 2000; Minamikawa, 2000). Diving behavior of internesting females varies with respect to habitat and maximum dive depths are often influenced by the offshore habitats (Houghton et al., 2002). For example, turtles residing in deeper water habitats typically dive deeper and have longer dive times. The purpose of the diving may also vary by location. Studies in Japan have concluded that loggerheads primarily rest on the seabed between nesting events (Minamikawa et al., 1997) and that much of loggerhead internesting behavior is dedicated to energy conservation (Minamikawa et al., 2000). However loggerheads will also make deep active dives in oceanographic frontal zones (Sakamota et al., 1990). These studies imply a behavioral plasticity among internesting loggerhead turtles.

Other studies have shown that loggerhead turtles may vary their dive behavior over the interesting interval. For example, turtles show increased time swimming near the surface, immediately after nesting and as the next nesting date approaches (Houghton et al., 2002). Houghton et al. (2002) also documented that female loggerheads spend more time near the surface during daylight hours than at night. Previous TDR studies have provided substantial information on loggerhead sea turtle dive and surfacing behav- 
ior (Houghton, 2002; Hays et al., 2002). They also demonstrate that habitat and oceanographic factors may lead to regional variation in the internesting dive and surfacing behaviors (Hays et al., 2002). To mitigate for specific conservation issues such as boat strikes, it is therefore important to understand turtle behavior within those areas where the problems occur and to account for environmental variables that might influence dive behavior.

Within the waters of Florida, boat strikes are a notable threat to loggerhead sea turtles and are increasing. By 2005, the number of boat licenses issued in the state of Florida surpassed one million representing a 2-fold increase in the last twenty-five year (Fig. 3) (Singel et al., 2007). Increasing water traffic is associated with the increasing probability of boat impacts on sea turtles in Florida (Fig. 4) as has been similarly documented for manatees (Rommel et al., 2007). The trends of increasing boat impacts on sea turtles prompt the present study to evaluate the risk to loggerheads from recreational water crafts and boat races in a region occupied by a large nesting aggregation of southwest Florida loggerhead turtles.

In addition to increasing recreational and commercial boat traffic another potential (but undocumented) factor is professional boat racing in near-shore waters. During the last decade boat racing in Florida has moved from offshore to near-shore events. This transition has increased the popularity of the sport for both the general public and sponsors because beach spectators can view the boat races from less than 60 feet away as they travel at up to $160 \mathrm{mph}$ across the race course. Several Florida boat races sponsored by Super Boat International Productions, Inc. are held each year with many boats in each race. The World Champion Offshore Powerboat Race in 2007 took place in Key West, 
Florida and was the largest powerboat competition in the world with over 85 boats in competition (www.superboat.com). However the movement to near-shore areas has also moved the racing into habitats frequented by loggerhead turtles during their internesting periods and thus increases the potential for boat strikes (Fig. 5). Five to six major boat races occur during the loggerhead nesting season in Florida (www.superboat.com) (Fig. 6).

Nearshore boat races have also increased the potential for recreational or spectator boat strikes. The annual Suncoast Offshore Grand Prix event is held in Sarasota, FL. This week long event (i.e. the 2008 event was scheduled from June 28-July 6) brings hundreds of thousands of people to Sarasota (www.findsarasota.com) to watch the races and participate in other boat related activities including the boat races, fishing tournaments, offshore parties, and fireworks. The event draws recreational boaters from all across the United States and other Countries. Such heavy boat traffic in nearshore waters from both recreational and sport boat racing coincides directly with peak loggerhead nesting season in Sarasota County. In addition, the event overlaps with the $4^{\text {th }}$ of July which is a date that includes increased recreational boating do to firework events on the coast.

\section{Marine Policy and Law}

The regulation of boating activities is important for protecting loggerhead turtles from boat strikes. Such regulations usually include speed restrictions. A study in Moreton Bay, Queensland, Australia concluded that turtles are at greater risk of being struck by boats that are traveling at increased speeds (Hazel et al. 2007). In the waters of Florida, speed zones are posted as "Idle Speed - No Wake" or "Slow Down - Minimum Wake." These designated zones are in place in shallow waters and narrow waterways 
such as intercoastal waters of Florida to protect manatees and sea grass beds (www.myfwc.com).

Under section 327.803 of Florida Statutes, the Boating Advisory Council (BAC) was created by the Florida Fish and Wildlife Conservation Commission (FWC) to advise the commission on affairs pertaining to Florida boating. Specifically the BAC makes recommendations to FWC and the Department of Community Affairs on issues concerning the Florida boating community which includes: boating safety, boat usage, and boatrelated services such as marinas, ports, and boat testing areas (www.myfwc.com).

Boat races occurring in Florida require a permit to operate in waters that are designated as a protected area. Under the Florida Administrative Code (F.A.C) Rule 68C22.03, a permit may be applied for to hold an organized boat race in a protected area. Permits are issued to boat races that meet the guidelines of individual county rules. Conditions are commonly placed on boat race permits. Examples of some conditions that are incorporated with boat race permits include: aerial surveys of the race area before and during the event to ensure there are no marine animals in the area; onboard marine observers are present to spot wildlife in the area (i.e. most notably manatees); and a limitation on the total number of boats in the race (www.myfwc.com). Such a regulatory structure provides the opportunity for studies, such as this one, to have a direct effect on mitigation policies. It is my intention to provide information gathered in this study to the BAC and FWC in support of policies that will reduce loggerhead sea turtle boat strikes in South West Florida. 


\section{Materials and Methods}

Time-Depth Recorders (TDRs) were attached to adult female loggerhead sea turtles during 2007 and 2008 summer nesting season to document water temperature and daily activity patterns. These Data Storage Tags $\left(\mathrm{DST}^{\mathrm{tm}}\right)$ made by Star-Oddi in Vatnagardar, Iceland were used for this study. DST-mill and centi TDR tags were programmed using the SeaStar software 3.8.5 made by Star-Oddi Ltd. Vatnagardar (http://www.staroddi.com). The DST-milli tags can record dive depths and water temperature and log up to 43,000 measurements with a fixed depth accuracy of $+/-0.4 \%$ at selected depth range (i.e. 0-20 $\mathrm{m}$ or 0-50 $\mathrm{m}$ ranges were used in the present study). DST-centi tags can record up to 174,000 measurements with a fixed depth accuracy of $+/-0.4 \%$ at selected depth ranges (i.e. $0-20 \mathrm{~m}$ or 0-50 $\mathrm{m}$ ranges were used in the present study).

DST-centi tags were set up in the single measurement sequence mode allowing the tag to take a measurement of dive behavior every $5 \mathrm{sec}$. for a consecutive of 43,500 measurements (see calculation 1). These tags were set up to capture 14 days of dive behavior.

DST-milli tags were set up in a multi-measurement sequence mode allowing the tags to take a measurement of dive behavior every $10 \mathrm{sec}$. for up to 360 measurements (see calculation 2). After 360 measurements the tag would switch into sleep mode for three hours. By logging 21,728 measurements on 10 second intervals only half of the memory of the tag was used, so the tag could be re-deployed on another nesting turtle after the tag was recovered. 
Tags were attached on female loggerhead turtles after nesting on Casey Key Beach in Sarasota County, FL (i.e. see Fig. 6 for location). Casey Key is one of five beaches monitored by Mote Marine Laboratory along a $58 \mathrm{~km}$ portion of the west Florida coastline. Remigrant (turtles who have nested in a previous season) loggerhead turtles were chosen as candidates for TDR attachments because opportunity for recovery is higher than in neophyte turtles and such individuals have better nest-site fidelity to Casey Key.

TDRs were attached to the carapace of nesting turtles with quick setting epoxy resin (Aquamend ${ }^{\mathrm{tm}}$ ) obtained at a local hardware store. Attachment methods varied slightly between the 2007 and 2008 season. In 2007 TDRs were attached to the rear portion of the carapace (Fig. 7). To prepare for attachment, the carapace was cleaned of epibiota, sanded, rinsed with multiple washes of water and denatured ethanol, and dried. After the surface was prepped the TDRs were secured with epoxy and the turtle restrained until the epoxy cured.

During the 2008 season, a pair of DST milli tags were placed on each turtle and programmed to run consecutively to record multiple days of dive behavior. With insight gleaned from the 2007 season, the location of attachment was changed and TDRs were attached to the third central scute on the carapace instead of the rear portion of the carapace (Fig. 8). This method involved removing barnacles from the carapace before TDRs were attached with the epoxy resin.

Very High Frequency (VHF) radio transmitters (AVM Instrument Company Colfax, California: model MP2 with single C cell battery) were attached to the third central scute of the carapace to enable turtles to be readily located on the nesting beach and aid 
in TDR recovery (www.avminstrument.com) (see Fig. 8 for attachment location). Attachment methods were identical to that used to attach TDRs in the 2008 season. The radio tags operated at a $151 \mathrm{MHZ}$ frequency. To determine transmitter location a VHF receiver, model R1000, and a foldable 3 element YAGI antennae (Advanced Telemetry Systems, model F150-3FB) were utilized.

Recovery probability of the TDR dataloggers was enhanced because of an ongoing loggerhead sea turtle identification tagging study on Casey Key Beach operated in concert with this dive study. Tagging patrols carried a VHF receiver in the field seven nights a week from May $15^{\text {th }}$ to July $31^{\text {st }}$ to enable easy detection of returned instrument equipped turtles. Tagging patrols were instructed to monitor the VHF receiver each hour between 9 p.m. to 5 a.m. A steady signal detected by the receiver informed the researchers on the beach that the turtle was ashore. Using a directional YAGI antenna allowed the tagging patrols to pin point the location of the turtle that was carrying a TDR tag.

Some turtles carrying TDRs and radio tags were also equipped with ARGOS Satellite linked time and depth records (satellite tags) which enabled us to track turtle locations throughout the interesting interval. Turtles carrying TDR units were closely monitored. When a turtle moved close to shore, the night-time tagging patrol was contacted with details about the expected nesting location. This information also informed the tagging patrols to listen for that turtle's transmitter via radio receiver.

Data gathered via satellite telemetry also helped us determine how far individual turtles were from shore, either by displacement (distance from initial deployment) or distance (distance from the adjacent shoreline). Such information was useful in determining the area of high use by turtles for correlation with boat high use areas. 
Finally supplemental depth data recorded from a previous study (2007-2008) using "National Geographic CritterCams" (www.nationalgeographic.com) were analyzed to assess dive behavior of female loggerhead turtles. These video recorders are capable of collecting up to 12 hours of video footage per deployment as well as dive depth and water temperature. After the recording session filled the memory capacity, the Crittercams were programmed to detach from the carapaces of the turtles and were usually found floating a couple of miles offshore. Recovery was conducted from a $21 \mathrm{ft}$ boat using a VHF receiver and directional YAGI antennae. Five female internesting loggerhead turtles were used is this study during the 2007 and 2008 loggerhead nesting season (2 crittercams were attached in June 2007 early in the season and 3 were attached in July 2008 late in the season).

When the turtles returned to nest instruments were removed from the carapace. TDR data was uploaded to a computer via the program SeaStar 3.8.5 and exported into Microsoft Office Excel $2003^{\text {tm }}$ to calculate surface time, mean dive depth, average number of dives, standard deviation and to develop a time budget on duration spent at specific depth ranges.

To assess the risk of boat strikes on turtles, a surface risk zone (SRZ) was calculated from an assessment of boat draft typical for Florida. According to a study of 1,500 recreational boat designs by Mellor (1992) draft can be modeled as Maximum Draft = $($ Length of Boat/10 $)+(0.3 \mathrm{~m})$. A 2002 survey of 1,175 boaters in Florida showed that 40 $\%$ of the vessels were $15-20 \mathrm{~m}$ in length (this was the highest percentage in the survey) (Thomas and Stratis, 2002). And in another study (Rommel et al., 2007) the far majority (98\%) of boats operating in Florida waters are less or equal to $12.2 \mathrm{~m}$. Thus, the maxi- 
mum draft of a powerboat of $12.2 \mathrm{~m}$ total length is $1.5 \mathrm{~m}$ and a boat of $15 \mathrm{~m}$ in length would have a maximum draft of $0.77 \mathrm{~m}$ (see Fig. 9 for calculation). I therefore set the SRZ of one meter below surface water as a conservative estimate that encompasses the majority of recreational boat traffic in Florida.

The amount of time spent with-in the SRZ was calculated for each turtle using its TDR record. The number of data points logged at a depth between 0-1 $\mathrm{m}$ was divided by the total number of data points recorded during the deployment to calculate the proportion of time the turtle spent in the SRZ (view calculation 3). Average and maximum dive depth was also calculated for each record using Microsoft Excel ${ }^{\mathrm{tm}}$. Individual dives were classified as any submergences that began with a depth greater than 0 and completed with a return to 0 (view calculation 3 and fig. 10). The total number of dives during the internesting period was divided by the total recording time of the TDR to calculate an average number of dives per hour (view calculation 3). The number of dives per hour was further subdivided by each day. Lastly, data points were binned into specific dive depths ranges to calculate the percentage of time spent at each depth range (view calculation 4).

The near shore environment (NSE) in this study was defined as a distance of $3 \mathrm{~km}$ from the nearest adjacent shoreline as determined by a visual examination of a nautical map illustrating the location of the Sarasota Boat Races. Such maps are generated by the Festival Steering committee, who is required to map the boat races to comply with the Super Boat International/APBA Inc. regulations stating that boat races must be less than or equal to 10 miles in length from start to finish and provide a viewing area for recreational boaters (see Fig. 11) (www.suncoastoffshore.org). We chose this delineation of the NSE because vessel traffic in and out of this area is high during the boat race events. 
Since this map lacks a scale bar, a nautical map of the Gulf of Mexico from NOAA (chart number 411) was overlayed with the boat race map (www.charts.noaa.gov). The farthest point of the spectator viewing areas from the adjacent shore line is observed at $3 \mathrm{~km}$. Three summers spent in Sarasota County (2006, 2007, and 2008), allowed me to become familiar with the boat race events (i.e. attended the boat race events in 2006 and 2007). Through direct observation, vessel traffic is exceedingly high within the spectator viewing area during the week long boat festival.

Distance-from-shore for each turtle was calculated using satellite telemetry information gathered during the 2005-2008 loggerhead nesting seasons. Turtle movements were reconstructed from latitude and longitude fixes of Location Classes 3, 2, 1, 0, and A (and omitted Location Classes of B or Z) (Hays et al. 2001). To compensate for inherent error in Argos reported locations, data was post-processed using a Satellite Tracking and Analysis Tool (STAT: Coyne and Godley 2005) to filter inaccurate locations using the parameters: depth $>+0.5 \mathrm{~m}$, travel rate $>4 \mathrm{~km} / \mathrm{hr}$ for consecutive locations, and angle of departure from a trackline of $<15$ degrees. Travel rate was calculated assuming straight line movements between the successive fixes. Distance between successive fixes was calculated using a great circle route equation. Distance, bearing, and other remotely sensed products were integrated in STAT and images were plotted in Maptool, a publicly available graphics tool provided by SEATURTLE.ORG (http://www.seaturtle.org). Bathymetric data were sampled from the General Bathymetric Chart of the Oceans GEBCO 1-minute Global bathymetry Grids. All tracks were publicly available and archived on the website www.seaturtle.org/tracking. 
The locations reported by the satellite tags during the internesting days of loggerhead turtles were used to evaluate the proportion of time turtles spent within the near shore environment (NSE) during their interesting intervals. So that all individual turtle data sets could be combined I subsampled each record to create equal sized records. Using Microsoft Excel ${ }^{\mathrm{tm}}$ distance from shore for values were randomly sampled every twelve hours, such that each subsample contain 2 high quality locations per hour. To account for accuracy differences, data points with $\mathrm{LC} 1,2$, and 3 were assessed differently with respect to distance from shore: an LC3 located from shore out to $2.75 \mathrm{~m}$ was within the NSE, an LC2 located from shore out to $2.5 \mathrm{~m}$ was within the NSE, and an LC1 located from shore out to $2 \mathrm{~m}$ was within the NSE. Once the interesting data was examined, the data sets were combined in a single analysis to report the percentage of time in the NSE. To assess the risk of boat strikes on loggerhead turtles, the amount of time spent near the surface within the NSE was determined from TDR data.

\section{Results}

The 2007 and 2008 TDR deployments totaled 377.5 hours of recorded loggerhead dive behavior or 135,552 depth sampling intervals with the use of 7 TDRs (Table 1). In 2007 data logger retention was a problem as 10 instruments were deployed and only 2 recovered. Dive data collected in 2007 provided data for two internesting intervals for a single loggerhead turtle (turtle A). One internesting period (June 9-10, 2007) provided $15 \mathrm{~h}$ of recording between a false crawl on June $9^{\text {th }}$ and a subsequent nest on June $10^{\text {th }}$ and $57 \mathrm{hr}$ (internesting period two) of data after nesting on June $10^{\text {th }}$. In 2008 , a total of 10 TDRs were deployed on 5 turtles. Six TDRs recovered in 2008 recorded data during 
three interesting intervals totaling 108,695 depth interval measurements for three interesting turtles. Tags were best retained when placed between the radio and satellite tag (i.e. there was a $100 \%$ recovery rate when attached to this location). One of the six recovered tags was damaged during the internesting period which caused a complete loss of data of this tag. However, the other tag recorded 3.5 days of dive behavior for turtle D (May 2730, 2008). Seven days of dive behavior for turtle B and C were recorded. One day of false crawl dive behavior (May 28, 2008) and six days of post-nesting dive behavior was recorded for turtle B (May 29-31, 2008 and June 4-7, 2008). Seven days of post-nesting dive behavior were recorded for turtle C (May 28-31, 2008 and June 4-7, 2008).

The three turtles in the 2008 TDR study were remigrants previous tagged on $\mathrm{Ca}$ sey Key Beach, FL. Size ranged from curved carapace measurements of $90.5 \mathrm{~cm}$ to 108 cm (Table 1). Turtle B was first tagged in 2002, while Turtle C and D were tagged in 2006. Turtle A and B are actually the same turtle that laid 6 nests in both the 2007 and 2008 seasons. Satellite Telemetry revealed that the short migration to Old Tampa Bay after the 2007 nesting season allowed the turtle to return in 2008.

The 2007 and 2008 Crittercam study recorded 42 hours of dive behavior for 5 loggerhead turtles. Crittercam A and B were recovered in the 2007 season and recorded 24 hours of post-nesting dive behavior. Crittercam C, D, and E were recovered in the 2008 season and recorded 18 hours of post-nesting dive behavior.

A single analysis of the percentage of time spent in the SRZ and mean dive depth was assessed for 10 internesting intervals with the use of seven TDRs and five crittercams (Table 2). Time in the SRZ was $9.8 \%$ of the daily time budget for the nine turtles 
in the TDR and crittercam study. Time in the SRZ ranged from 1.5-22.4\% (Table 2). An average mean dive depth of $8.2 \mathrm{~m}$ was documented in this analysis.

Individual statistics from the 2007 and 2008 Crittercam study are represented in Fig. 12 and Fig. 13 and Table 2. Fig. 12 and Fig. 13 represent binned data for time spent at each individual depth. Time in the SRZ and mean and max dive depth differed among the 5 turtles in this study.

Turtle A in the 2007 Crittercam study spent $12.7 \%$ of the daily time budget in the SRZ for 12 hours of recorded dive behavior. During this time she averaged a depth of 3.3 meters. Max dive depth was seen at a depth of 12 meters. A large percentage of the daily time budget was spent just below the SRZ (i.e. turtle A spent $23 \%$ of time at depths from 2-3 meters).

Turtle B in the 2007 Crittercam study spent $8.6 \%$ of the daily time budget in the SRZ for 12 hours of recorded dive behavior. During this time she averaged a depth of 5.6 meters. Max dive depth was seen at a depth of 10 meter. Turtle B spent time at deeper dive depths when compared to turtle A (i.e. turtle B spent $32 \%$ of time at depths from 7-8 meters).

Turtle $\mathrm{C}$ in the 2008 Crittercam study spent $22.4 \%$ of the daily time budget in the SRZ for 6 hours of recorded dive behavior. During this time she averaged a swim depth of 4.7 meters. Max dive depth was seen at a depth of 6.52 meters. A large portion of the daily time budget was spent at depths $6-7$ meters; $70 \%$ of time was spent at depths from $6-7$ meters. Overall, $92.2 \%$ of the daily time budget was spent at depths from $0-1$ meters and 6-7 meters. Very little time was spent at depths from 2-5 meters (i.e. only about 5\% of the time was spent at depths from 2-5 meters). 
Turtle D in the 2008 Crittercam study spent $9.8 \%$ of the daily time budget in the SRZ for 6 hours of recorded dive behavior. During this time she averaged a depth of 3.6 meters. Max dive depth was seen at a depth of 5.9 meters. Increased amounts of time were spent at depths from 3-6 meters when compared to that of depths from 0-3 meters. Turtle D spent $70 \%$ of the daily time budget at depths from 3-6 meters.

Turtle E in the 2008 Crittercam study spent $1.5 \%$ of the daily time budget in the SRZ for 6 hours of recorded dive behavior. During this time she averaged a depth of 4.3 meters. Max dive depth was seen at a depth of 7.9 meters. Like turtle D, turtle E spent large portions of time at depths from 3-6 meters (i.e. $78 \%$ of the daily time budget was spent at depths from 3-6 meters).

Individual dive statistics from the 2007 and 2008 TDR study are represented in Table 2 and 3. Table 3 shows a comparison of time spent in the SRZ and number of dives per hour for the first $24 \mathrm{~h}$ interesting period versus the average of all interesting data following this period. For example, the first $24 \mathrm{~h}$ interesting period for turtle A was from June 9-10, 2007 and the following period was from June 11-14, 2007. The first 24 $\mathrm{h}$ period for turtle $\mathrm{A}$ and $\mathrm{B}$ represent a period following a false crawl event and subsequent nest. The number of dives and time spent in the SRZ was high following a false crawl when compared to the interesting period following the first 24 hours after nesting. Turtle A spent $18.7 \%$ in the SRZ and made 4 dives an hour following a false crawl which is greater than the internesting period from June 11-14, 2007. Also, time in the SRZ following the false crawl event on June $9^{\text {th }}$ was much higher than the average time in the SRZ for all TDR and crittercam turtles (i.e. the average time in the SRZ for all TDR and crittercam turtles was 9.7\%; see Table 2). Turtle B spent $8.1 \%$ in the SRZ 
zone following a false crawl event which is slightly greater than time spent in the SRZ after the first $24 \mathrm{~h}$ of interesting data (Table 3).

In 2007 the TDR study showed an increased number of dives and time spent at the surface during morning hours as compared to late afternoon and early evening hours. Increased surface activity and number of dives in the 2008 study was not tied to a specific time of day. Individual statistics for the 4 interesting turtles in the TDR study varied with respect to dive depth, time of increased activity, standard deviation, and time spent in the SRZ.

Turtle A averaged 4 dives an hour and a mean dive depth of $5 \mathrm{~m}(3.1 \mathrm{sd})$ following the false crawl event on June $9^{\text {th }}$. The increased number of dives immediately following the false crawl event exacerbated the average number of dives per hour (i.e. the turtle averaged around 9 dives an hour during the first three hours after the false crawl event). The number of dives made during the morning hours was low when compared with the first few hours after false crawling and last few hours before returning to the beach to nest.

Three days of post-nesting dive behavior (June 11-14, 2007) for turtle A concluded a mean dive depth of $14.9 \mathrm{~m}$ (sd 3.9). During this time the turtle averaged 2.5 dives an hour. High activity periods during the morning hours increased the number of dives made hour. Figure 14 reveals that the loggerhead turtle made a significant number of dives between the hours of 9 a.m. -11 a.m. on the first day after nesting. The most dives made on the first day were documented between the hours of 9 a.m. - 10 a.m. (during this time 8 dives were made; refer to Fig. 14). 
Six days of post-nesting dive behavior along with one day of post-false crawl dive behavior concluded a mean dive depth of $11.5 \mathrm{~m}$ (sd 4.6) for turtle B. During this time the turtles averaged 2.1 dives an hour. After the false crawl event the turtle averaged a 6.3 $\mathrm{m}$ mean dive depth which was $5 \mathrm{~m}$ shallower than the overall mean dive depth. High activity periods after the false crawl event increased the number of dives made on day one (i.e. turtle B averaged 4.62 dives an hour following the false crawl event, see Fig. 15). The number of dives made an hour decreased from day 1 to day 8 (Fig. 15). The deepest dive was made on the $8^{\text {th }}$ day in the dive interval at 16.6 meters

Seven days of post-nesting dive behavior concluded a mean dive depth of $11.21 \mathrm{~m}$ (sd 4.4) for turtle C. During this time the turtle average 1.7 dives an hour. The average number of dives per day was consistent throughout the 7 days of recorded dive behavior. The numbers of dives during days 1-3 were slightly above the overall average number of dives for turtle $\mathrm{C}$ (Fig. 15). Like turtle B, turtle $\mathrm{C}$ gradually made deeper dives when comparing days $1-11$ of the internesting interval. The deepest dive was made on the $4^{\text {th }}$ day in the dive interval at 16 meters.

Post-nesting dive behavior for turtle D concluded a mean dive depth of $14.5 \mathrm{~m}$ (sd 8.1). The turtle averaged 3.2 dives an hour. High activity periods after the nesting event increased the number of dives made on day one (i.e. turtle $\mathrm{D}$ averaged 7 dives an hour following the nesting event, see Fig. 15). The number of dives made an hour decreased from day 1 to day 4 (Fig. 15). The deepest dive was made on the $4^{\text {th }}$ day in the dive interval at 23 meters.

Satellite tags deployed on 40 female loggerhead turtles during the 2005-2008 seasons recorded 1,927 internesting days. Time in the NSE averaged 34.5\% for the 40 tur- 
tles in this study. The SRZ was overlayed with time spent in the NSE for 3 time periods: $24 \mathrm{~h}$ following a nesting event or nesting attempt, $24 \mathrm{~h}$ prior to a subsequent nest, and internesting data following the first $24 \mathrm{~h}$ of a nesting event.

Time in the SRZ was $12.5 \%$ of the daily time budget for turtle A during four days (June 9-14, 2008) of dive behavior (Table 2). During the time in the SRZ the turtle spent $50 \%$ of the time within the NSE. Time in the danger zone was increased on June $10^{\text {th }}$ (period following false crawl) where the turtle spent the entire day in the NSE and $18.7 \%$ of that time was spent in the SRZ. Three days of post-nesting dive behavior, June 11-14, 2007, revealed that turtle A spent $6.3 \%$ of the time in the SRZ and $33.3 \%$ of that time in the NSE. This turtle was recorded outside the NSE $12 \mathrm{~h}$ after nesting on June 10, 2007. Overall, $23 \%$ of the time spent in the SRZ was between the morning hours of 8 a.m. -12 p.m. Low periods of activity were documented during evening hours and the first few hours after nesting.

Time in the SRZ was $6.9 \%$ of the daily time budget for the seven days of dive behavior for turtle B (Table 2). Like turtle A, this spent the entire day in the NSE following the unsuccessful nesting attempt event on May 28, 2008 and 8.1\% in the SRZ at this time. During the six days of documented post-nesting dive behavior (May 29-31, 2008 and June, 4-7), turtle B spent $6.7 \%$ of the time in the SRZ (Table 3) and $12.7 \%$ within the NSE. This turtle stayed within the NSE during the first $24 \mathrm{~h}$ after nesting. Percentage of time in the SRZ was high through the first 3.5 days of recorded dive behavior when compared to that of days 8-11 (Fig. 16). Turtle B spent increased amounts of time in the SRZ in the late evening hours on day 1 (i.e. turtle B spent an increased amount of 
time in the SRZ before returning to the beach to nest). Post-nesting dive behavior of turtle B didn't show a trend in increased surface time with respect to a specific time of day.

Time in the SRZ was 6.8\% of the daily time budget for seven days (May 28-31, 2008 and June 4-7, 2008) of post-nesting dive behavior for turtle C (Table 2). During the time in the SRZ the turtle spent $20 \%$ of the time within the NSE. This turtle was recorded outside the NSE $12 \mathrm{~h}$ after nesting. Increased surface time was seen during the $3^{\text {rd }}$ day of internesting were $10.63 \%$ of the daily time budget was spent in the SRZ (Fig.16). Like turtle B, this internesting turtles showed high activity periods at different times of the day when comparing day to day surfacing intervals.

Time in the SRZ was $6.5 \%$ of the daily time budget for the 3.5 days (May 27-30, 2008) of post-nesting dive behavior for turtle D. During the time in the SRZ the turtle spent $16.7 \%$ of the time within the NSE. This turtle was recorded outside the NSE $12 \mathrm{~h}$ after nesting. Increased surface time was seen during the $2^{\text {nd }}$ day of internesting were 8.93\% of the daily time budget was spent in the SRZ (Fig.16). Turtle D showed a trend of increased time spent in the SRZ during morning hours. The loggerhead turtle averaged around 9\% of time in the SRZ during the hours of $6-10$ a.m.

To compare the time spent in the surface risk zone, the depths used by loggerhead turtles B, C and D were plotted as a percentage of time spent at each depth (Fig. 17). When plotted as a percentage turtle B spent the most time in the SRZ. 


\section{Discussion}

The 2007 and 2008 TDR study along with four years of data from 2005-2008 satellite tags revealed that loggerhead turtles are most vulnerable to boat strikes following a false crawl event, within $12 \mathrm{~h}$ after nesting and the night before returning to the beach to nest. It is during this time that turtles are closest to shore and also subject to high traffic boat areas. Our study showed that female turtles that had an unsuccessful nesting attempt typically reside in waters within $2 \mathrm{~km}$ of the adjacent shore line for the entire day before attempting to nest again placing them at elevated risk. Since time spent in the SRZ was high throughout most of the day for turtle A and B following a false crawl event, it might also suggests periods of rest (Houghton et al., 2002) as turtles recover from the energy expenditure of a false crawl event. Loggerhead turtles use up large amounts of energy following a false crawl event. As part of the tagging patrols on Casey Key Beach, a number of turtles false crawled multiple times in one given night. While we don't have enough data to correlate the number of false crawls with increased risk exposure in the SRZ it is conceivable that onshore activities which lead to an increasing proportion of false crawls (e.g. human disturbance, poor quality nesting beaches due to renourishment, etc.) actually increase risk to the turtle by subjecting to a higher incidence of boat strikes. This study suggests that female turtles face more than just increased levels of stress following a false crawl. During the week long boat festival in Sarasota, FL the probability of a false crawl could be increased due to fireworks events and increased nigh-time traffic on the beach from people that come to Sarasota for the boats races.

For turtles that were successful at nesting, they only spent a part of the day in the NSE following the nesting event. Generally they moved through the NSE to offshore 
areas within $12 \mathrm{~h}$ after nesting. There was some variation to this patter, however. Turtle $\mathrm{A}, \mathrm{C}$, and D were recorded outside the NSE $12 \mathrm{~h}$ after nesting while turtle B spent the entire day in this zone following its nesting event on May 29, 2008.

The four turtles in the TDR study showed a pattern of spending increased amounts of time in SRZ while within the NSE as compared to outside the NSE. While in the NSE during the first $24 \mathrm{~h}$ after nesting, turtle B spent $8.1 \%$ (Table 3) in the SRZ which represents an increase over time in the SRZ when outside the NSE. This increase was also seen for turtle A during the first $24 \mathrm{~h}$ after nesting. Turtle A spent $6.3 \%$ of the daily time budget in the SRZ while in the NSE which represents an increase when compared to time in the SRZ when outside the NSE. This trend was also seen for turtle D but not turtle C. Turtle D spent $7 \%$ of time in the SRZ while in the NSE which is an increase compared to the average time spent in SRZ when outside the NSE. Turtle C only spent $6 \%$ of the time in the SRZ while in the NSE. The average of time spent in the SRZ for this turtle while outside the NSE was around $8 \%$.

The five turtles in the Crittercam study did show a trend of increased time spent in the SRZ following a nesting event. Three of the five turtles (Crittercam turtle A, C, and D) recorded time in the SRZ that was greater than the overall average of time spent in the SRZ for all TDR and Crittercam turtles (i.e. the overall average was $9.7 \%$; see table 2). The increased amount of time spent in the SRZ following a nesting event provides a good indicator of time when turtles are most at the surface during post-nesting dive behavior. While the time in the NSE was unable to be calculated for the Crittercam turtles it is expected that the turtles spent the entire recording session $(12 \mathrm{~h}$ was the maximum recording session) in the NSE. This is based on what was seen in the TDR study and the 
distance from shore the Crittercams were retrieved (i.e. Crittercams were usually retrieved a couple of miles off shore).

The number of dives and average dives per hour was only weakly related to the amount of time spent within the SRZ. While in a few cases an increased number of dives per hour were reflected in the amount of time spent at the surface most turtle did not show this dive behavior. Turtle B showed an increased number of dives and time spent in the SRZ throughout day 1 of the internesting cycle. Other turtles differed in showing increased surface time with a low number of dives (i.e. turtle C spent $10.63 \%$ in the SRZ while averaging only 2.1 dives an hours). Thus, to measure the risk of boat strikes in terms of dives per hour is less accurate than a direct measure of time spent near the surface in the SRZ.

The nine turtles in the TDR and Crittercam study did show a pattern of increased amounts of time spent in the SRZ during the morning hours. Six out of nine turtles spent increased amount of time near the surface during the morning (i.e. 8 a.m. to 12 p.m.) as compared to afternoon and night time hours. Two of the four turtles in TDR study showed a preference of spending an increased amount of time in the SRZ during the morning hours (i.e. turtle A and D). The five turtles in the crittercam study also showed an increased amount of time in the SRZ during the morning hours with the exception of turtle E. When looking at time spent at the surface following a nesting event, which also happens to be in a zone close to shore, the morning hours provides a segment of time when turtles are most vulnerable to boat strikes. Boating is most notable in the morning and afternoon hours, especially during the boat races that are typically scheduled around the 10 a.m. hour (www.superboat.com). 
In the satellite tag study, that includes 40 interesting turtles from 2005-2008, the loggerhead turtles spent $34.5 \%$ of the time in the NSE. The percentage of time in the NSE is exacerbated by false crawls and the period before nesting events. Conservation actions concerning boat strikes should focus on the fact that loggerhead turtles spent large amounts of time within this boating high use zone. To shift or minimize risk of boat impacts, management actions should include both temporal and spatial recommendations. During the nesting season it must be considered that nearshore areas, closer than $3 \mathrm{~km}$ of the coast represent areas for high encounter raters with turtles. Recommendations to protect nesting loggerhead turtles are made in the response to current boating laws in the state of Florida. While the field components of my study are specific to Sarasota County, Florida, the diving patterns and statistics provide significant new management insight that might apply across 580 miles of Atlantic and 770 miles of Gulf coastline and to one of the highest per capita segments of US public boating (Singel et al., 2007).

The "idle" and "no-wake" speed zones in intercoastal ways provides little protection for internesting loggerhead turtles (Singel et al., 2007) because satellite telemetry shows that female turtles rarely frequent intercoastal water. Female loggerhead turtles use areas that are directly adjacent from nesting beaches which in most cases are absent to "ilde" and "no-wake" zones. A better awareness plan needs to be put into effect to help protect female turtles using zones directly adjacent from nesting beaches. Increased speeds have been reported in studies from Australia to intensify the risk of boat strikes (Hazel et al., 2007). Public outreach campaigns from these studies have been known to have encouraging effects on protecting turtles (Hazel et al. 2007). A user group recommendation in Florida would be to target the recreational boating industry. With Florida 
being a tourist state, not all boaters operating in the NSE are aware of the effects boating has on nesting turtles. Furthermore, boaters age 21 or younger are not required to take a Florida boater education class if they are non-residents and have met boater education requirements in the state of their residence (www.myfwc.com). Outreach should start at local boating marinas that rent boats to vacationer that come to Florida. The program is two fold: (1) to make people aware of the currents boating laws in Florida; (2) to increase the awareness of both sea turtle nesting season and of impacts increased boat speeds has on turtles.

One spatial recommendation would include moving the boat race back into Sarasota Bay. This recommendation would provide more protection for nesting female turtles, but the boat races would need a special permit because of the operation in a protected area (www.myfwc.com). Sarasota Bay is a protected area under the National Estuary Program. The Sarasota Bay Estuary Program was named in the Water Quality Act of 1987 as an area that was in need of a comprehensive plan to protect the water within the estuary. A spatial recommendation to move the races in this region would not only be a difficult task, it might also have a negative effect on other wildlife residing in the bay. The Sarasota Bay is home to bottlenose dolphins, juvenile turtles, manatees, blue crabs, and several species of fish (http://www.gulfbase.org).

A more realistic alternative as a spatial recommendation would be to shorten the boat race course. The current race course is approximately $10.5 \mathrm{~km}$ long which covers the area adjacent to Lido Beach between New Pass to Big Pass Sarasota. While nesting numbers are low on Lido Beach, neighboring beaches see large numbers of loggerhead nests (i.e. Siesta Key and Longboat Key). The recommendation is to shorten the race 
course so it does not expand pass Lido Key (Map: Fig. 11; www.suncoastoffshore.org). This will narrow the area the boat races use in the near shore environment. In theory, turtles that show nest-site selection to neighboring beaches will have less of chance of being impacted by boat because the race course doesn't extend to their nesting beach.

Equal consideration can be given to the human aspect of an alternative spatial recommendation. Shortening the boat race course may increase the spectator viewing window from shore. A current long boat race track allows only some of the race to be seen from the beach. A shorter course would allow spectators from shore to view the entire race which could minimize the extra vessel traffic from offshore spectators. A decrease in the number of boats using the NSE during the week of the boat races would diminish the probability of turtles being struck by boats.

Temporal recommendations include: (1) scheduling races outside the peak of nesting season or (2) conducting races in the afternoon rather than the morning. The loggerhead nesting season in Florida is from May-August. Late June and early July is peak loggerhead nesting season in Florida which coincides with the Sarasota Boat Races. Scheduling the boat races in the late afternoon hours may help protect female turtles that have nested or false crawled the night before the race. This recommendation however doesn't address the number of boats in NSE during the week long event (i.e. the Sarasota Boat Races occur a day or two before Fourth of July weekend).

Scheduling the boat races outside of the nesting season would greatly decrease the probability of boat strikes on female turtles because female turtles would be dispersed to home forging grounds. The temporal recommendation applies to both the Sarasota Boat Races and spectators that watch the races from their boat. Vessel use in the NSE is high 
around the time of the boat races. A temporal recommendation would decrease the overall traffic during the peak loggerhead nesting season. An alternative strategy of scheduling the boat races for a different time of year might increase the overall attendance of the event. The Sarasota Boat races are scheduled during the low tourist season in Florida. Temperatures can reach up to $100^{\circ} \mathrm{F}$ in early July when the boat races are scheduled. Scheduling the boat races outside of sea turtle nesting season and in high tourist season could benefit boat race sponsors and local business.

In order for temporal and spatial recommendations to be effective, a holistic approach must be taken to protect loggerhead turtles. The TDR and satellite tracking study identified that turtles that false crawl spend a significant amount of time at the surface and in the near-shore environment. Artificial lighting in Florida is a notable distraction for nesting loggerhead turtles. Most coastal counties have adopted a "lights-out policy" on turtle nesting beaches. Enforcement of the lighting ordinances is stricter in some counties than in others, but the overall threat of artificial lighting has not disappeared in Florida (Salmon 2003). For the purpose of this study, the recommendation would be to put increased enforcement on lighting during the Sarasota boat race events to prevent false crawls during a time period of notable boat traffic. 


\section{Acknowledgements}

A special thanks to Dr. Tony Tucker of Mote Marine Laboratory who helped guide this project in its entirety. Thanks to all staff and interns in the Sea Turtle Research and Conservation Program at Mote Marine Laboratory who helped me collect data for this project. Also I thank Dr. Scott and Karen Eckert for their insight on this project.

I also thank Virginia Miller for funding the TDRs. I also thank our partners and sponsors: Crittercams: Kyler Abernathy \& Greg Marshall- National Geographic. Field and boat logistics: Jen Beggs, Ryan Welsh, Maureen and Chuck Snyder. Tag sponsors: Florida Sea Turtle License Plate Grants, Mote Scientific Foundation, Wooster School, New Canaan Country School/Jeniam Foundation, Anna Maria Island Turtle Watch, 1-800Endoscope, Coastal Wildlife Club,Sarasota County Environmental Services, Longboat Key Turtle Watch, Norcross Wildlife Foundation, NASA Signals of Spring, WhaleNet, Virginia Miller, Penelope Kingman, 207 citizen scientists through online adoptions at Seaturtle.org. Rocket Science: Sirtrack, Wildlife Computers, CLS-Argos

GIS Analysis: Michael Coyne, Seaturtle.org, Inc./STAT/ Maptool Charlotte Girard, Collecte Localisation Satellite. Bioacoustics- David Mann- USF. 


\section{Sources and Literature Cited}

Avminstrument.com. May 2007. AVM Instrument Company, Ltd. 17 Jan. 2008 $<$ www.avminstrument.com $>$.

Bradshaw, C.A., McMahon, C.R., and G.C. Hays. 2007. Behavioral Inference of Diving Metabolic Rate in Free-Ranging Leatherback Turtles. J. Physiological and Biochemical Zoology. 80(2): 209-219.

Com-Spec.com. May 2007. Communication Specialists Inc. 21 Aug. 2008 $<$ http://www.com-spec.com/>.

Cites.org. 10 Oct. 2008. Convention on International Trade in Endangered Species of 1 July $2008<$ http://www.cites.org/eng/app/appendices.shtml $>$.

Coyne MS, Godley BJ (2005) Satellite Tracking and Analysis Tool (STAT): an integrated system for archiving, analyzing and mapping animal tracking data. Mar Ecol Prog Ser 301:1-7

Eckert, S.A. 2002. Swim speed and movement patterns of gravid leatherback sea turtles (Dermochelys coriacea) at St. Croix, U.S. Virgin Islands. J. Experimental Biology. 205: 3689-3697.

Eckert, S.A., Nellis, D.W., Eckert, K.L., and G.L. Kooyman. 1986. Diving pattering of two leatherback sea turtles (Dermochelys coridacea) during internesting intervals at Sandy Point, St. Croix, US Virgin Islands. J. Herpetologica. 42: 381-388.

Ecos.fwc.gov. March 2007. Recovery Plan (1991) for U.S. Population of Loggerhead Turtle. < http://ecos.fws.gov/docs/recovery_plans/1991/911226a.pdf>.

En.mimi.hu. 20 Nov. 2008. Definition of Boat Draft. $<$ http://en.mimi.hu/boating/draft.html $>$.

FindSarsota.com. 20 Nov. 2008. Suncoast Offshore Grand Prix. $<$ http://www.findsarasota.com/suncoastoffshore.htm>.

Gulfbase.org. 15 Oct. 2008. Sarasota Bay National Estuary Program. $<$ http://www.gulfbase.org/organization/view.php?oid=sbnep $>$.

Hays, G.C., Broderick, A.C., Glen, F., Godley, B.J., Houghton, J.D.R., and J.D. Metcalfe. 2002. Water Temperature and internesting intervals for loggerhead (Caretta caretta) and green (Chelonia mydas) sea turtles. J. Thermal Biology. 27: 429-432.

Hays, G.C., Forman, D.W., Harrington, L.A., Harrington, A.L., Macdonald, D.W., and D. Righton. 2006. Recording the free-living behavior of small-bodied shallow-diving nimals with data loggers. J. Animal Ecology. 76: 183-190.

Hays GC, Åkesson S, Godley BJ, Luschi P, Santidrian P (2001). The implications of location accuracy for the interpretation of satellite tracking data. Animal Behavior 61:1035-1040.

Hazel, J. and Gyuris, E. 2006. Vessel-related mortality of sea turtles in Queensland, Australia. J. Wildlife Research. 33:149-154.

Hazel, J., Lawler, I. R., Marsh, H., and S. Robison. 2007. Vessel speed increases collision risk for the green turtle Chelodina mydas. J. Endangered Species Research. 3:105-113.

Heithaus, M. R., McLash, J. M., Frid, A., Dill, L. M., and G. J. Marshall. 2002. Novel insights into the behavior of sea turtles from animal borne cameras. J. Marine Biological Association UK 82: 1049-1050. 
Houghton, J.D.R., Broderick, A.C., Godley, B.J., Metcalfe, J.D., and G.C. Hays. 2002. Diving Behavior during the internesting interval for loggerhead seaturtles Caretta caretta nesting in Cyprus. J. Marine Ecology Progress Series. 227: 63-70.

IUCNredlist.org. 13 Oct. 2008 World Conservation Union (IUCN) "Red List." Oct. 2008 $<$ http://intranet.iucn.org/webfiles/doc/SSC/RedList/redlistcatsenglish.pdf $>$.

Mellor., D. C.1992. Modern Marina Layout and Design. J. Civil Engineering Practice. 87-102.

Minamikawa, S., Naito, Y., Sato, K., Matsuzawa, Y., Bando, T., and W. Sakamoto. 2000. Maintenance of Neutral Buoyancy by Depth Selection in the Loggerhead Turtle Caretta Caretta. J. Experimental Biology. 203 (19): 2967-2975.

Minamikawa S., Naito Y., and I. Uchida. 1997. Buoyancy control of the loggerhead turtle, Caretta caretta. J. Ethology. 109: 109-118.

MyFWC.com. 11 Oct. 2008. Office of Legislative Affairs. $<$ http://myfwc.com/About/index.htm>.

MyFWC.com. 11 Oct. 2008. Florida Fish and Wildlife Conservation Commission Boating Advisory Council. <http://myfwc.com/boating/council/>.

MyFWC.com. 11 Oct. 2008. Florida Fish and Wildlife Conservation Commission. Florida Law Enforcement Branch. $<$ http://myfwc.com/Boating/council/aboutus.html $>$.

MyFWC.com. 12 Oct. 2008. Summary of Boating Safety Laws. $<$ http://myfwc.com/boating/safety/law_summary.htm $>$.

MyFWC.com. 12 Oct. 2008. Florida Education Laws. $<$ http://myfwc.com/ boating/safety/education_law.htm>.

MyFWC.com. 12 Oct. 2008. Boating Citations. $<$ http://myfwc.com/boating/safety/citations.htm>.

MyFWC.com. 12 Oct. 12 2008Florida Fish and Wildlife Conservation Commission. Access to Protected Areas. $<$ http://myfwc.com/manatee/permits/protectedareas.htm $>$.

MyFWC.com. 10 Oct. 2008. 2008 Nest Survey Results Do Not Change Turtle Nesting Trends $<$ http://research.myfwc.com/features/view_article.asp?id=27537>.

Nauticalcharts.noaa.gov. 15 Oct. 2008. Gulf Coast NOAA Nautical Charts. http://www.charts.noaa.gov/OnLineViewer/411.shtml

NMFS.noaa.gov. 10 Mar. 2007. Endangered Species Act of 1973. $<$ http://www.nmfs.noaa.gov/pr/pdfs/laws/esa.pdf $>$.

Norem, A. D. (2006). Injury Assessment of Sea Turtles Utilizing the Neritic Zone of the Southeastern United States. Master of Science thesis University of Florida. 112 pp.

Rommel, S., Costidis, A., Pitchford, T., Lightsey, J., Snyder, R., and E. Haubold. 2007. Forensic Methods for Characterizing Watercraft from watercraft-induced wounds on the Florida Manatee (Trichechus Manatus Latirostris). J. Marine Mammal Science. 23(1): 110-131.

Salmon, M. 2003. Artificial Night Lights and Turtles. J. Biologist. 50 (4). 163-168.

Sakamota W, Uchida I, Naito Y, Kazuo K, Tujimura M, and K. Sato. 1990. Deep diving behaviour of the loggerhead turtle near the frontal zone. J. Nippon Suisan Gakkaishi. 56: 1433-1453. 
Sato, K., Sakamoto W., Matsuzawa, Y., Tanaka, H., Minamikawa, S., and Y. Naito. 1995. Body temperature independence of solar radiation in free-ranging loggerhead turtles, Caretta caretta, during internesting periods. J. Marine Biology. 123: 197-205.

Sato, K., Sakamoto W., Matsuzawa, Y., Tanaka H., and Y. Naito. 1994. Correction between stomach temperature and ambient water temperatures in free-ranging loggerhead turtles, Caretta caretta. J. Marine Biology. 118: 343-351.

Seaturtle.org. May 2007. Satellite tracking tool from seaturtle.org $<$ http://www.seaturtle.org/tracking/>.

Singel, K., Foley, A., and R. Bailey. 2007. Navigating Florida's waterways: boat related strandings of marine turtles in Florida. In: Proc. 27th Annual Symp. on Sea Turtle Biology and Conservation. Myrtle Beach, S.C.: International Sea Turtle Society.

Southwood, A. L., Andrews, R. D., Lutcavage, M. E., Paladino, F. V., West, N. H., George, R. and D.R. Jones. 1999. Heart rates and dive behavior of leatherback sea turtles in the eastern Pacific ocean. J. Experimental Biology. 202: 1115-1125.

Superboat.org. 15 Sept. 2007. General Information. <http://www.superboat.com $>$.

Superboat.org. 15 Sept. 2007. Super Boat International boating schedules. $<$ http://www.superboat.com/events.cfm?action=details\&id=101>.

Suncoastoffshore.org. 20 Sept. 2008. Super Boat International Nautical Chart. $<$ http://www.suncoastoffshore.org/images/officialmap.gif $>$.

Star-oddi.com. 10 Sept. 2008. Star-Oddi LTD. <http://www.star-oddi.com>.

Thomas, M., and N. Stratis. 2002. Compensating Variation for Recreational Policy: A Random Utility Approach to Boating in Florida. J. Marine Resource Economics. 17: 23-33.

Webster, W.M. and Kelly A. Cook. 2000. Intraseasonal Nesting Activity of Loggerhead Sea Turtles (Caretta caretta) in Southeastern North Carolina. J. The American Midland Naturalist. 145 (1). 66-73. 


\section{$\underline{\text { Calculations }}$}

\section{Appendix 1}

Calculation 1: The DST-centi tags were set up the single measurement sequence mode. A measurement was taken every $5 \mathrm{sec}$. The Start time for DST-centi tags ranged from 13 a.m. for the 2007 nesting season. Below is just a sample calculation the time and start date different of what is showed below. This calculation was made in the SeaStar Program.

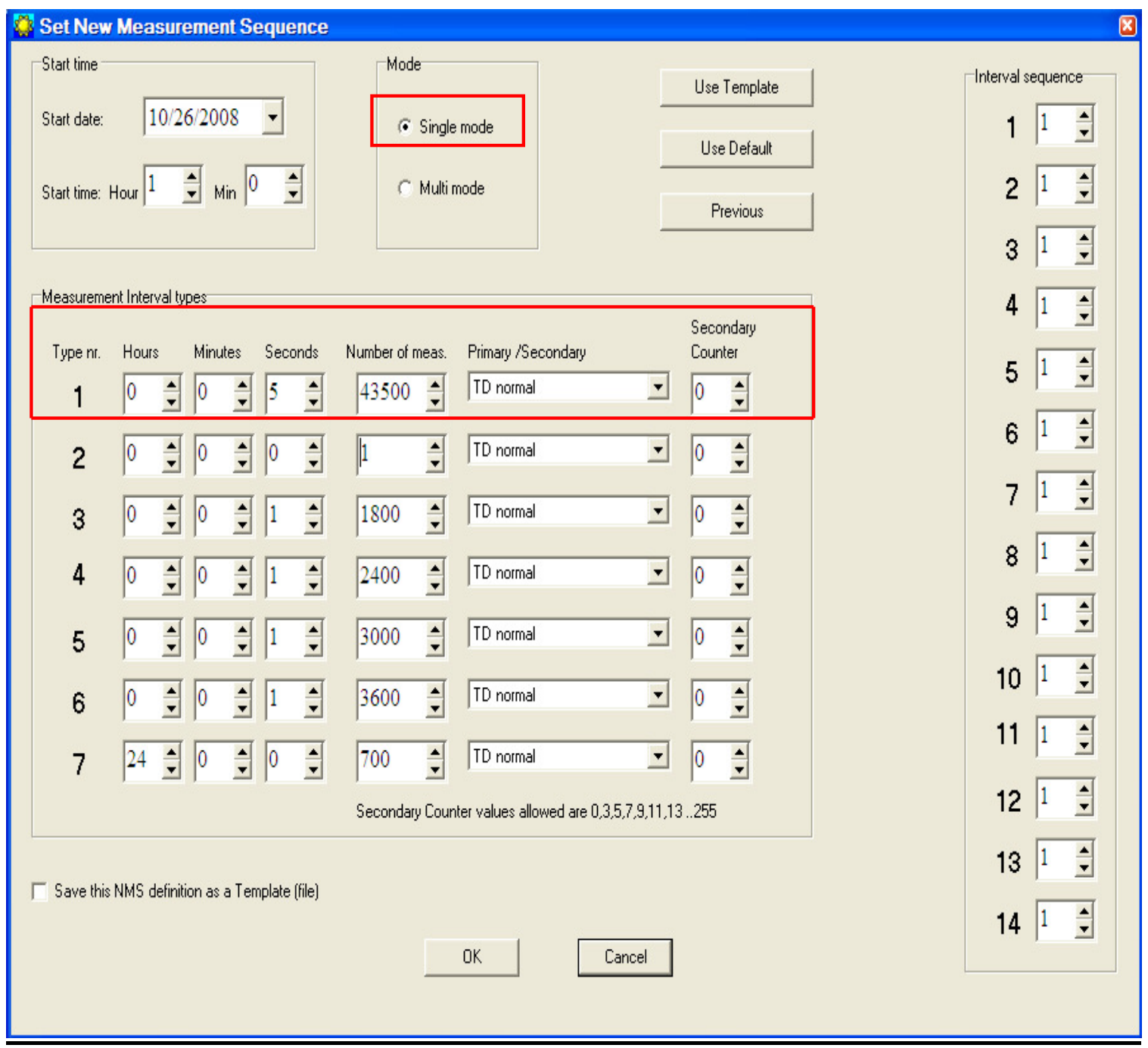


Calculation 2: The DST-Milli Model tags were set up to take 360 measurement and then switch to sleep mode for 3 hours. To do this they were set up in the multi-measurement sequence mode where the interval sequence would cycle from measurement interval type 1 and 2. The Start time for DST-centi tags ranged from 1-3 a.m. for the 2007 and 2008 nesting season. Below is just a sample calculation the time and start date different of what is showed below. This calculation was made in the SeaStar Program.

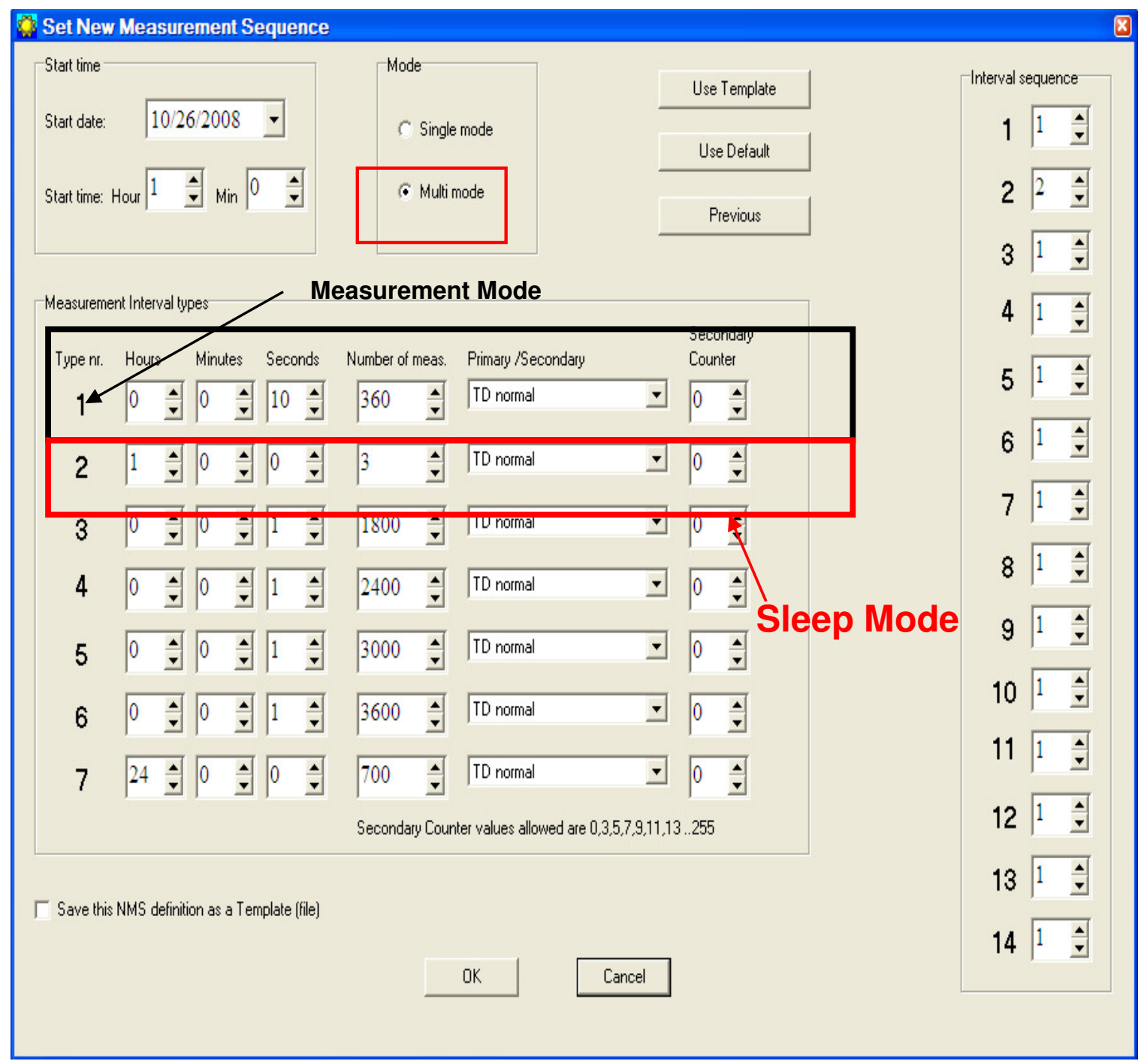


Calculation 3: A) The time the tag was in sleep mode was documented. B) The time the tag was in sleep mode was subtracted to get the total number of hours the tag recorded. C) The number of measurements in the surface risk zone was multiplied by the total number of data points recorded by the TDR to get the percentage of time in the SRZ. D) A individual dive started and ended at a depth of 0 meters; the total number of dives was recorded for each turtle. E) The number of dives was divided by the total number of hours recorded to get the average number of dives an hour.

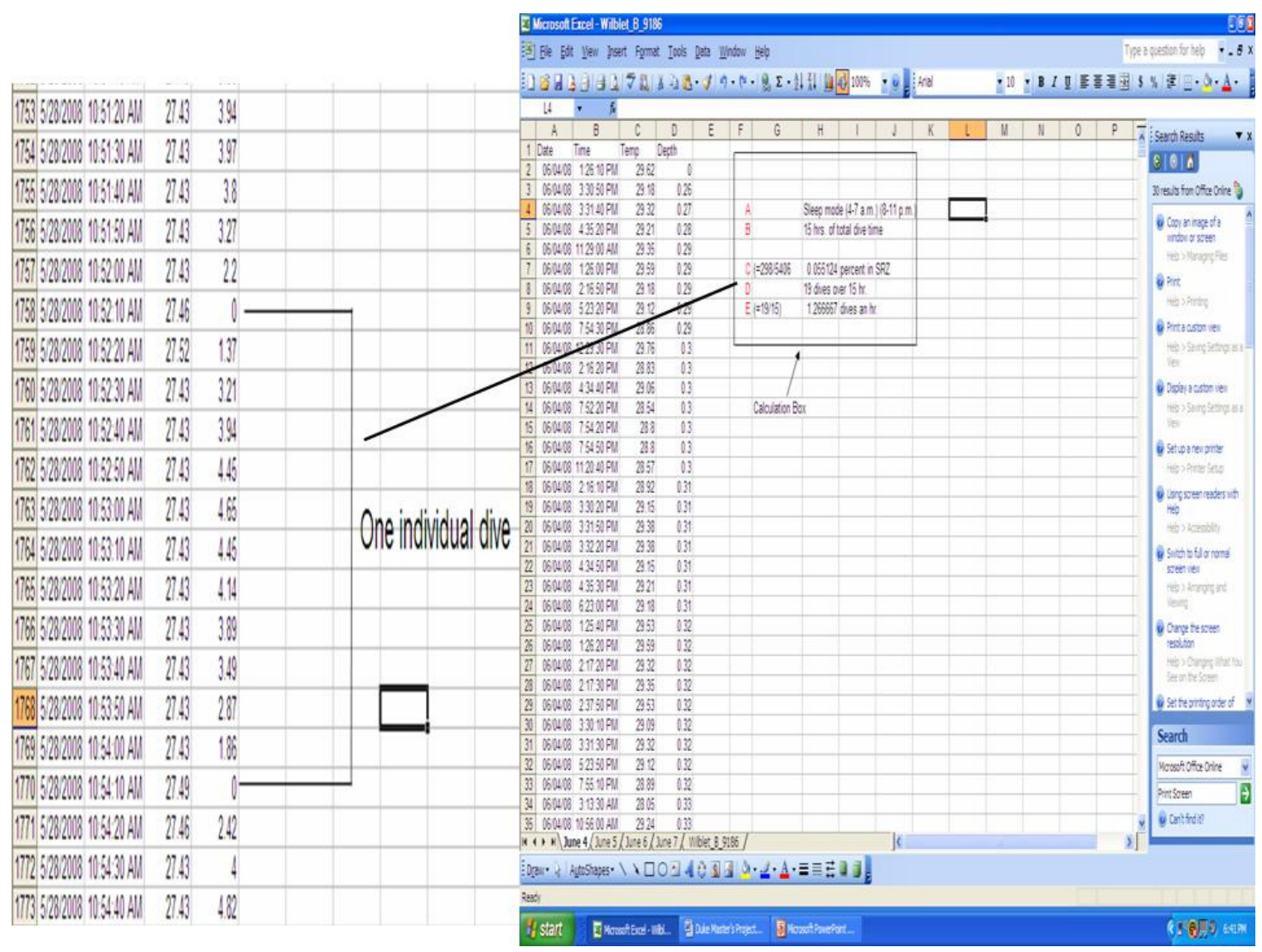


Calculation 4: The time spent at each individual depth was calculated for each day in the internesting individual. The number of measurements at each depth was divided by the total number of measurements to get the percentage of time spent at that depth.

\begin{tabular}{|c|c|c|c|c|c|c|c|c|c|c|c|c|c|c|c|c|c|}
\hline 59 Depth & 1 & 0 & .1 & 2 & .3 & 4 & .6 & 6 & .7 & .8 & .9 & .10 & .11 & .12 & .13 & $.14<$ & 4.15 \\
\hline 60 Day 1 & 125 & 483 & 62 & 190 & 243 & 154 & 77 & 140 & 3092 & 68 & 0 & 0 & 0 & 0 & 0 & 0 & 0 \\
\hline 61 Day 2 & 0 & 600 & 139 & 373 & 401 & 219 & 128 & 312 & 178 & 1175 & 1729 & 1401 & 804 & 12 & 0 & 0 & 0 \\
\hline 62 Day 3 & 0 & 520 & 465 & 123 & 54 & 34 & 109 & 330 & 278 & 256 & 122 & 149 & 253 & 1330 & 1121 & 484 & 846 \\
\hline 63 Day 4 & 0 & 164 & 9 & 5 & 5 & 3 & 3 & 5 & 11 & 15 & 14 & 5 & 9 & 4 & 7 & 12 & 2000 \\
\hline 64 Day 8 & 0 & 298 & 36 & 75 & 19 & 11 & 24 & 63 & 35 & 37 & 30 & 44 & 49 & 47 & 289 & 871 & 3465 \\
\hline 65 Day 9 & 100 & 361 & 15 & 8 & 8 & 13 & 20 & 31 & 27 & 49 & 64 & 45 & 62 & 27 & 28 & 339 & 6352 \\
\hline 66 Day 10 & 0 & 491 & 12 & 14 & 13 & 9 & 20 & 27 & 32 & 29 & 57 & 56 & 30 & 18 & 31 & 1006 & 3910 \\
\hline 67 Day 11 & 17 & & 0 & 12 & 0 & 7 & 3 & 8 & 2 & 9 & 3 & 6 & 5 & 7 & 7 & 2072 & 5 \\
\hline 68 Total & $242^{\prime}$ & 2917 & $738^{\prime}$ & $800^{\prime}$ & $743^{\prime}$ & $450^{\prime}$ & $304^{\prime}$ & $916^{\prime \prime}$ & $44555^{\prime}$ & $1638^{\prime}$ & $2019^{\prime}$ & $1706^{\prime}$ & $1300^{\prime}$ & 1445 & $14833^{\prime}$ & 5584 & 16578 \\
\hline 69 & 43476 & 43476 & 43476 & 43476 & 43476 & 43776 & 43776 & 43476 & 43476 & 43476 & 43476 & 43476 & 43.376 & 43476 & 43476 & 43476 & 43476 \\
\hline 70 Average & 0.055566 & 0.067094 & 0.016975 & 0.018401 & 0.01709 & 010351 & 0.0080320 & 0.021069 & 0.10247 & 0.0376760 & 0.046439 & 0.03924 & 0.029002 & 0.033237 & 0.034111 & 0.128439 & 0.381314 \\
\hline 71 Percentage & 0.556029 & 6709449 & $1.607480^{\circ}$ & 1.840996 & 1.700909 & 035054 & 0.803246 & 2.10691 & 10.24703 & 37675964 & 6643941 & 3.924004 & 2990155 & 3323673 & 3.411077 & 12.84387 & 38.13138 \\
\hline & & & & & & & & & & & & & & & & & \\
\hline
\end{tabular}




\section{$\underline{\text { Tables }}$}

\section{Appendix II}

Table 1: Summary of results for the 2007 and 2008 study. Results are from the 2007 and 2008 TDR study and satellite tag study. CCL stands for curved carapace length.

\begin{tabular}{|c|c|c|c|}
\hline & \multicolumn{2}{|c|}{ Summary of Dive Results } & \multirow[b]{2}{*}{$\mathrm{CCL}$} \\
\hline $\begin{array}{l}\text { Turtle } \\
\text { ID }\end{array}$ & Recorded dive time (hr.) & \# of Measurements & \\
\hline $\mathrm{A}$ & 76 & 26857 & 108 \\
\hline$B$ & 120.6 & 43478 & 108 \\
\hline $\mathrm{C}$ & 120.6 & 43478 & 90.5 \\
\hline $\mathrm{D}$ & 60.3 & 21739 & 99.8 \\
\hline & Total: 373.4 & Total: 135552 & \\
\hline
\end{tabular}

Table 2: Single Analysis for Percentage of Time in SRZ for 4 TDR turtles and 5 Crittercam turtles.

Percentage of Time in the SRZ

\begin{tabular}{|l|r|r|}
\hline Turtle & \% SRZ & \multicolumn{2}{|c|}{ Mean Dive Depth $(\mathrm{m})$} \\
\hline A & 12.5 & 9.6 \\
\hline B & 6.9 & 11.5 \\
\hline C & 6.8 & 11.2 \\
\hline D & 6.5 & 14.5 \\
\hline Crittercam A & 12.7 & 3.3 \\
\hline Crittercam B & 8.6 & 5.6 \\
\hline Crittercam C & 22.4 & 4.7 \\
\hline Crittercam D & 9.8 & 5.9 \\
\hline Crittercam E & 1.5 & 7.9 \\
\hline Average & & 8.244444444 \\
& 9.744444444 & \\
\hline
\end{tabular}

Table 3: Comparison of Dive Behavior Between 1st $24 \mathrm{~h}$ and the Following Interesting Period

\begin{tabular}{|l|r|r|r|r|}
\hline Turtle ID & \% SRZ (1st 24 h) & \% SRZ (After 24 h) & \# Dives an h (1st 24 h) & \# Dives h (After 24 h) \\
\hline A & 18.7 & 6.3 & 4 & 2.5 \\
\hline B & 8.1 & 6.7 & 4.6 & 1.7 \\
\hline C & 6.1 & 6.9 & 2.4 & 1.6 \\
\hline D & 6.6 & 6.4 & 7 & 1.9 \\
\hline
\end{tabular}




\section{Appendix III}

\section{Figures}

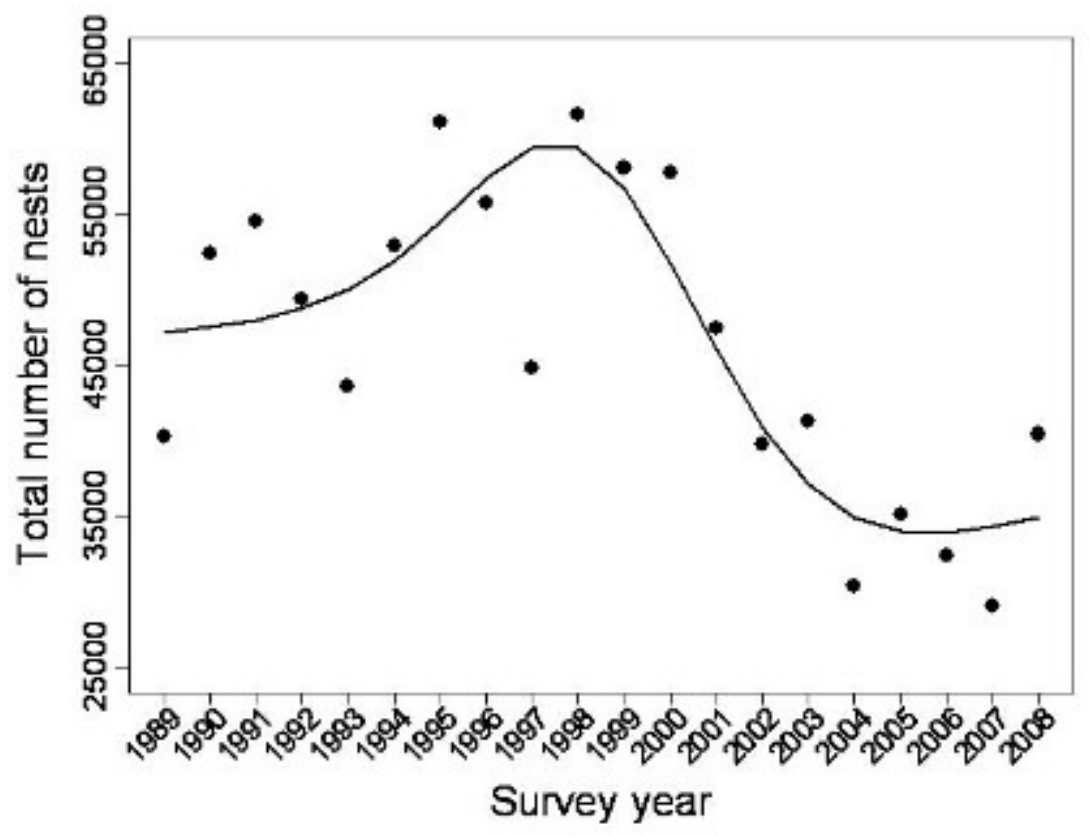

Fig. 1. Annual Total Nests Counts for Loggerhead Sea Turtles. From FWC http://research.myfwc.com/features/view_article.asp?id=27537.

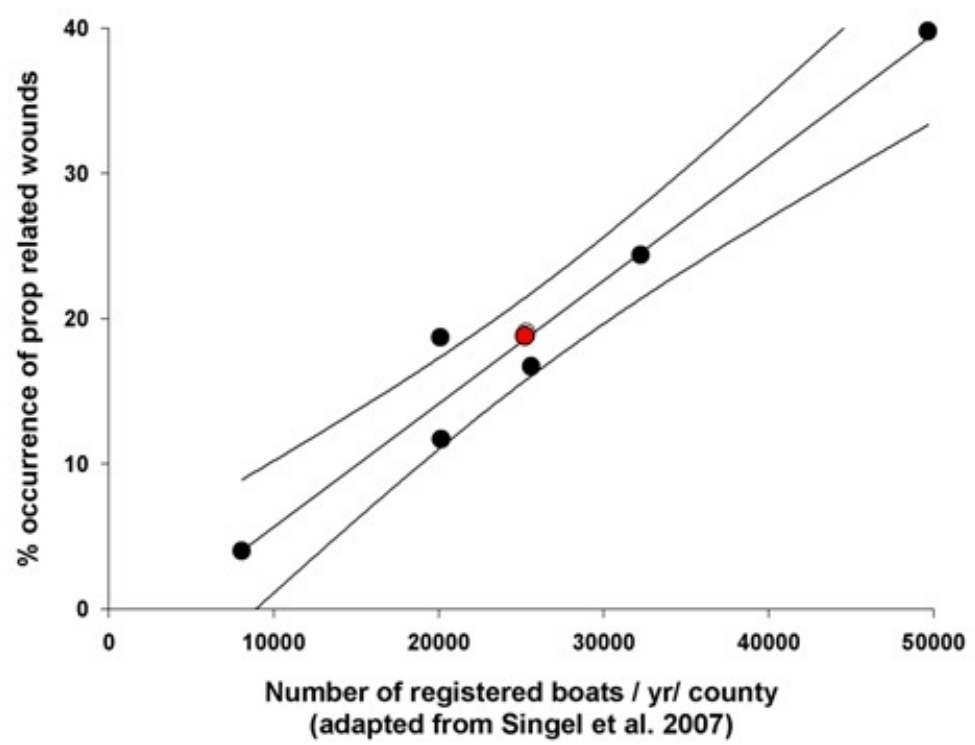

Fig. 2. Trend of regional boat registrations plotted against \% occurrence of prop related wounds. Sarasota Co. is plotted in red. 


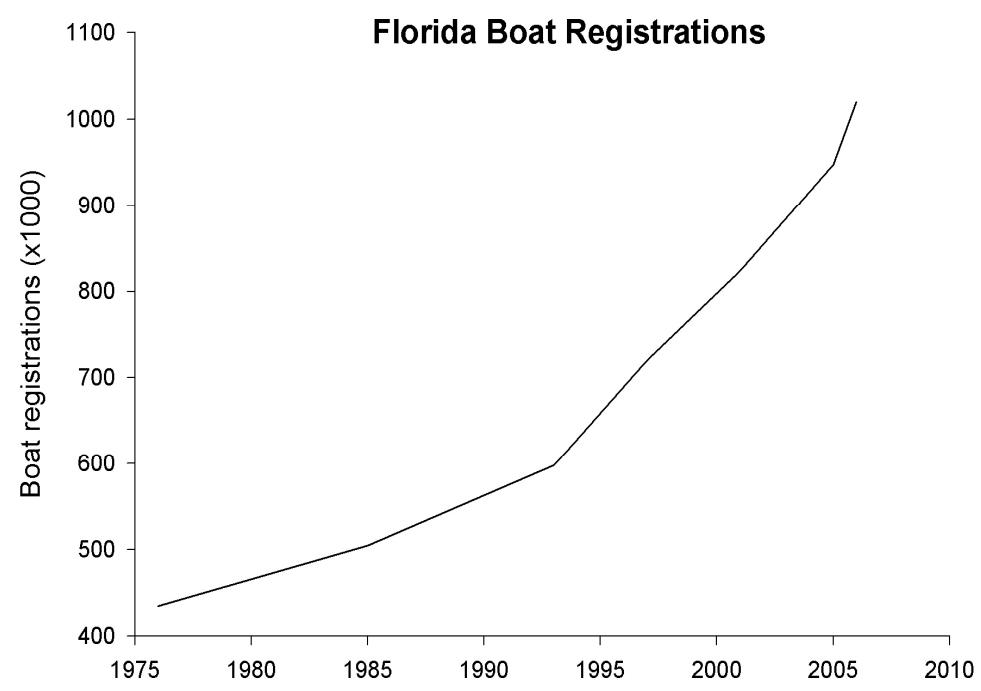

Fig. 3. Trend of Florida Boat Registrations from 1976 to 2006. Currently 1 out of 11 Florida residents have a boating license (FDHSMV 2007).

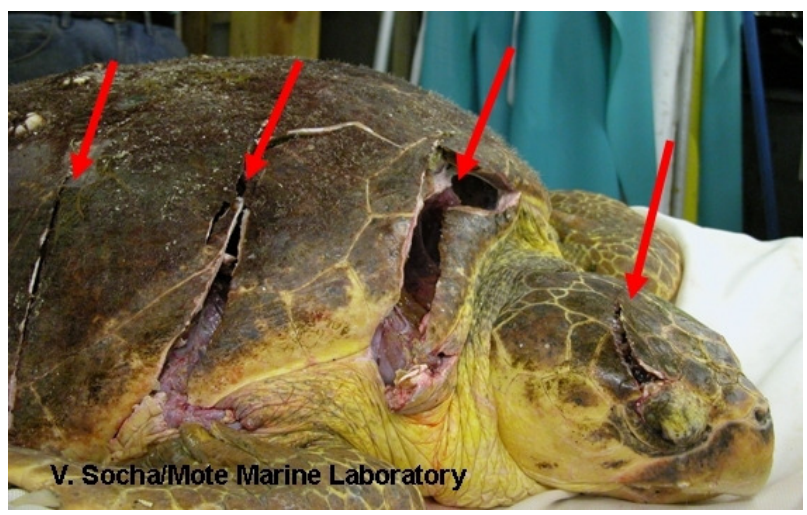

Fig. 4. Boat prop strikes on carapace. 1 in 5 stranded loggerheads has evidence of boat impact (Singel et al. 2007). 


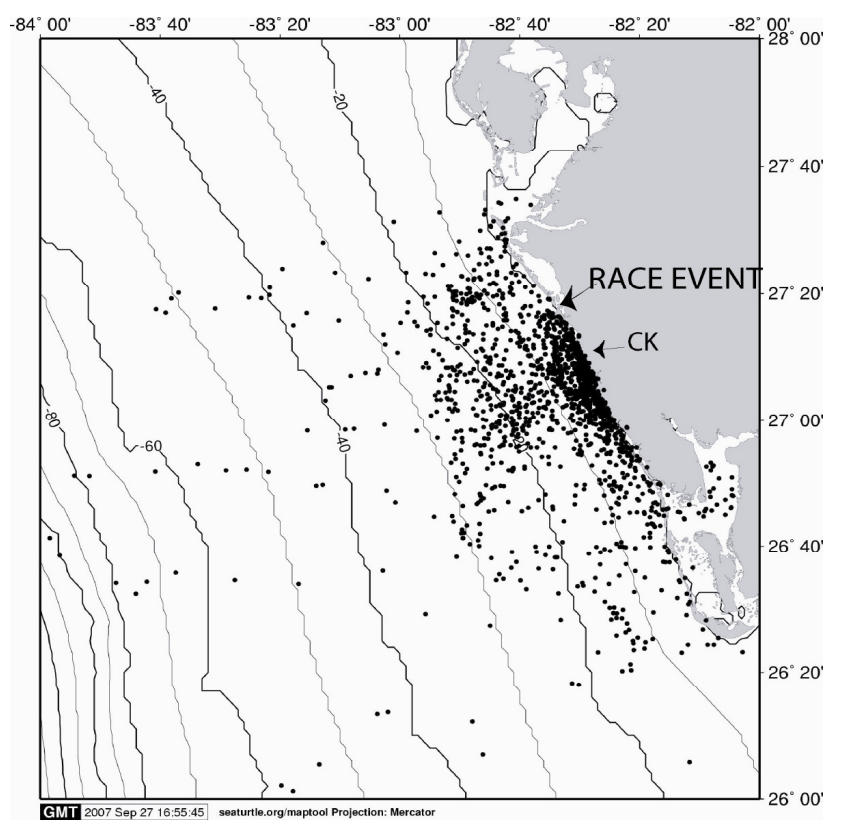

Fig. 5. Turtle density near the rookeries is high during the internesting periods (from Tucker and Coyne- submitted).

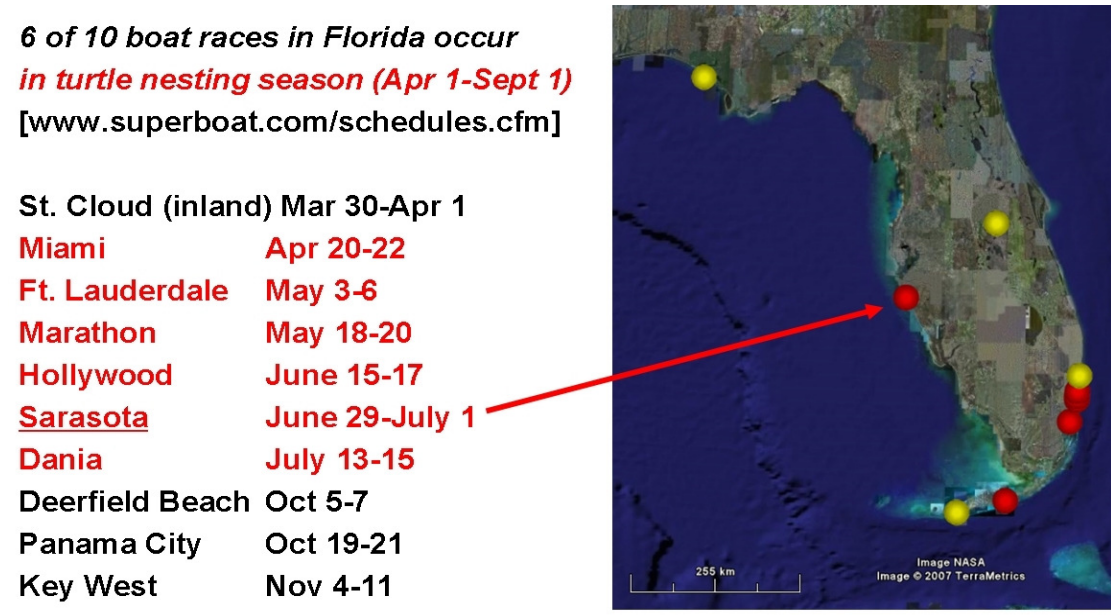

Fig. 6. Boat races occurring in Florida are adjacent to several high density loggerhead rookeries for the Atlantic and Gulf of Mexico. 


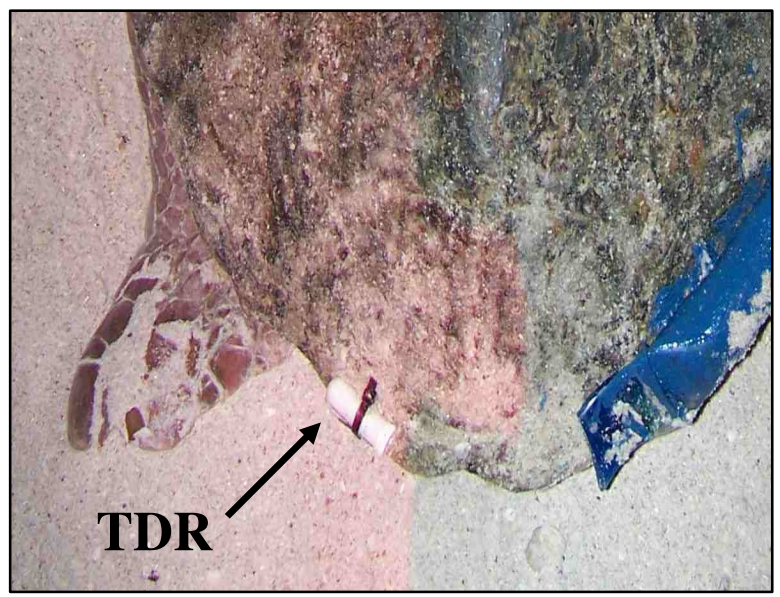

Fig. 7. TDR attachment site on a loggerhead.(Photo credit: A.D. Tucker).

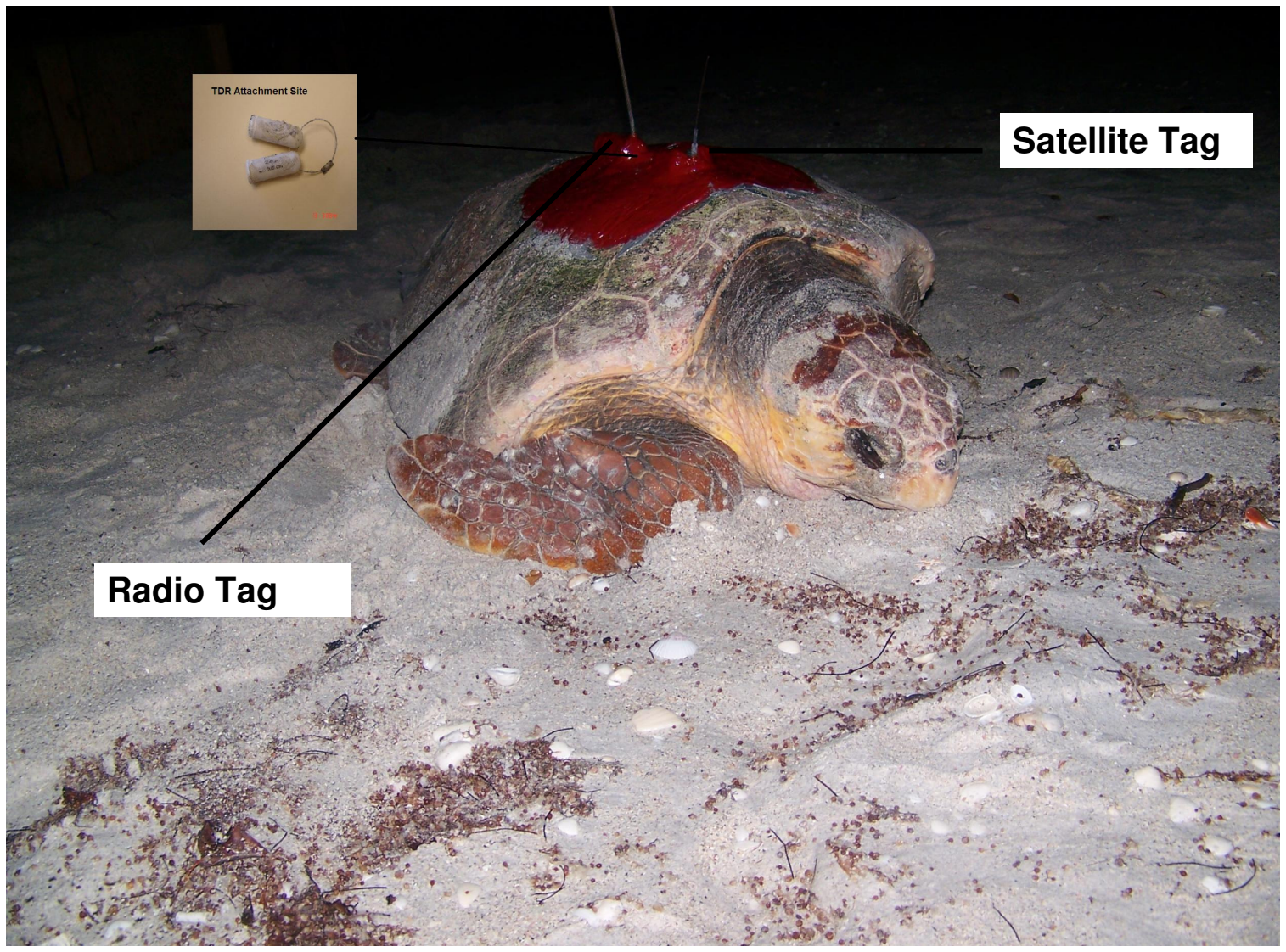

Fig. 8. Attachment sites of 2008 transmitters. (Photo Credit: A.D Tucker). 


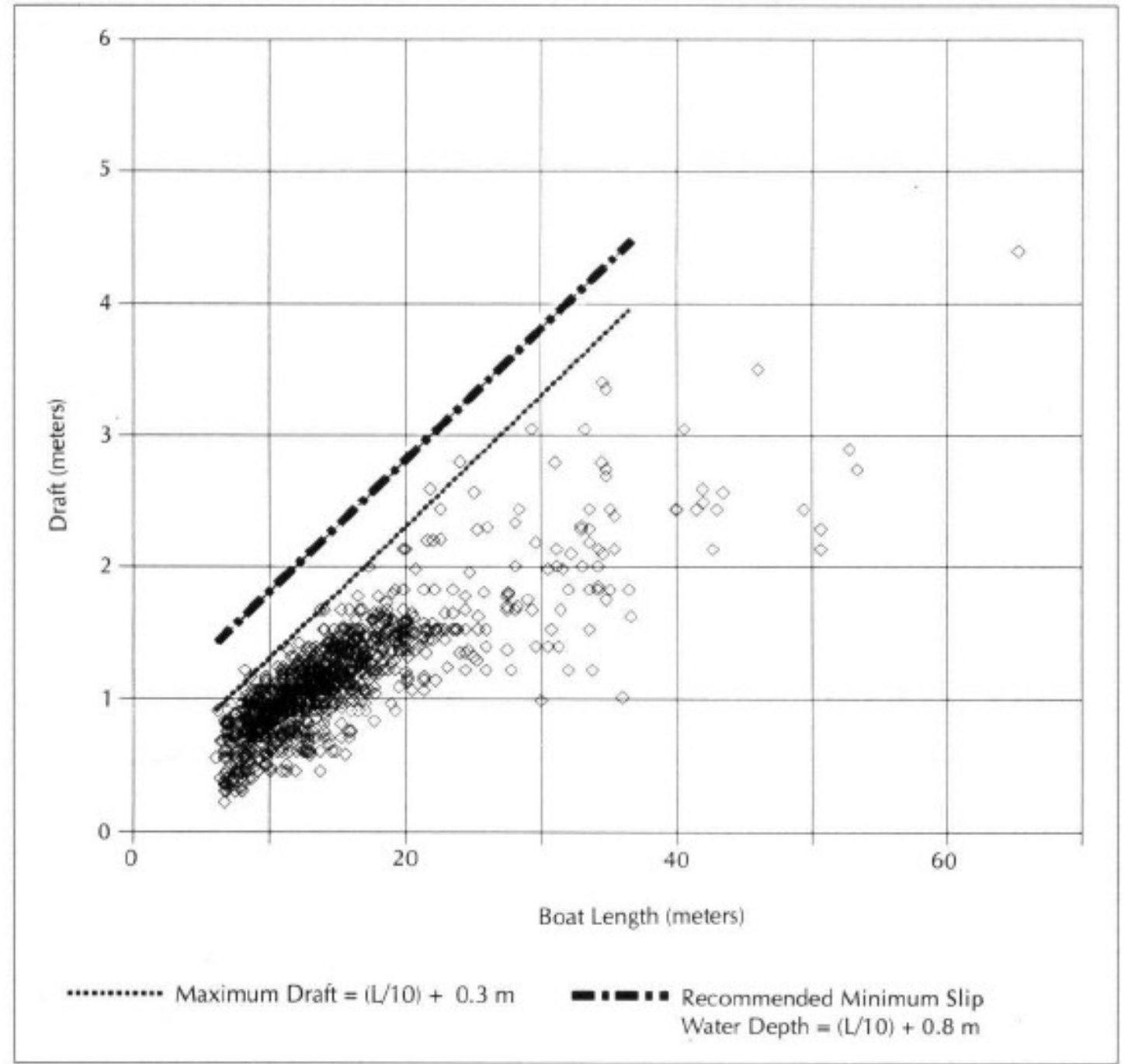

FIGURE 9. A plot of powerboat draft against overall boat length. Figure from Mellor, 1992. 


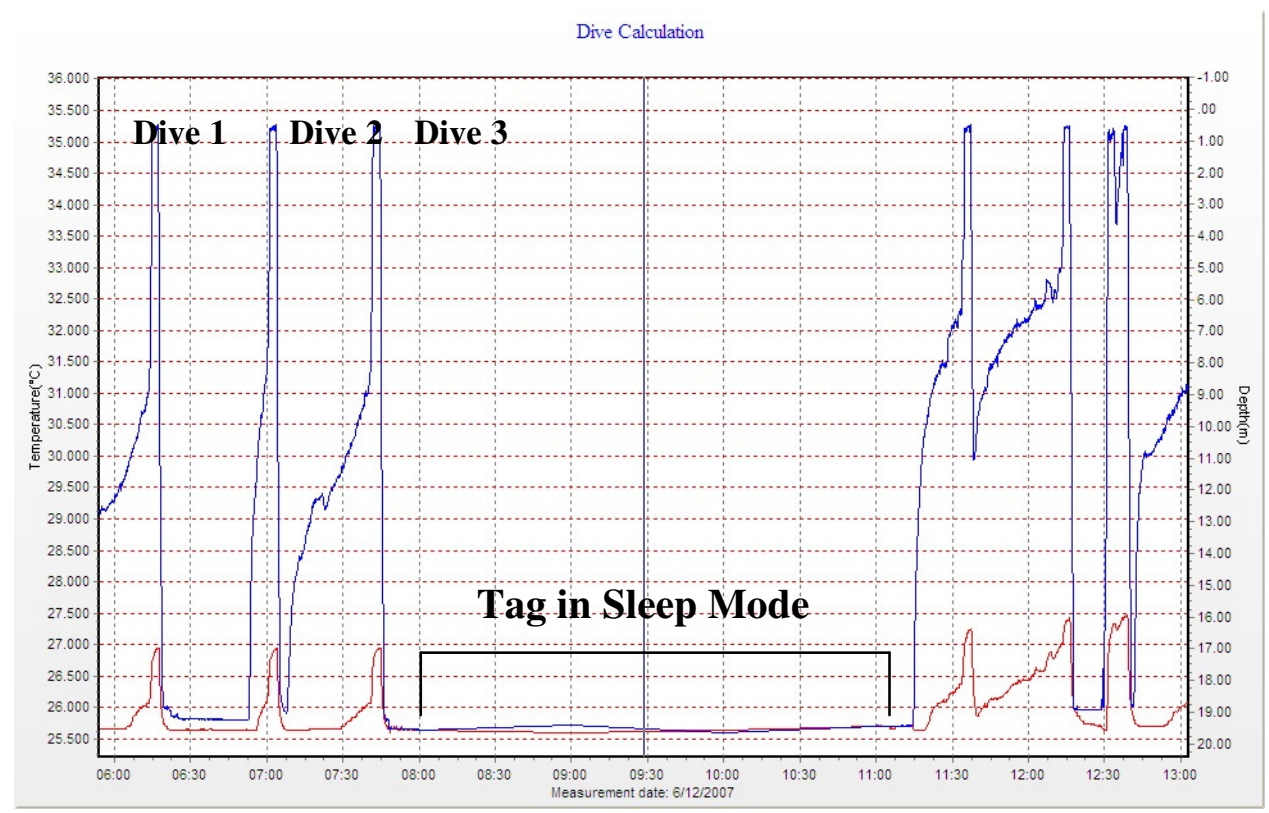

Fig. 10. An individual dive was defined as the period between surface water events. This graph is from the sea star program that represents a segment of dive data for a loggerhead turtle. The blue line represents depth and red is water temperature. During a $24 \mathrm{hr}$. recording session, the DST-milli tags were set up to go into sleep mode for $3 \mathrm{hrs}$. This figure is a visual representation of sea turtle dives. The number of dives an hour was calculated using Microsoft Excel (graph constructed using 2007 dive data: Sobin and Tucker). 


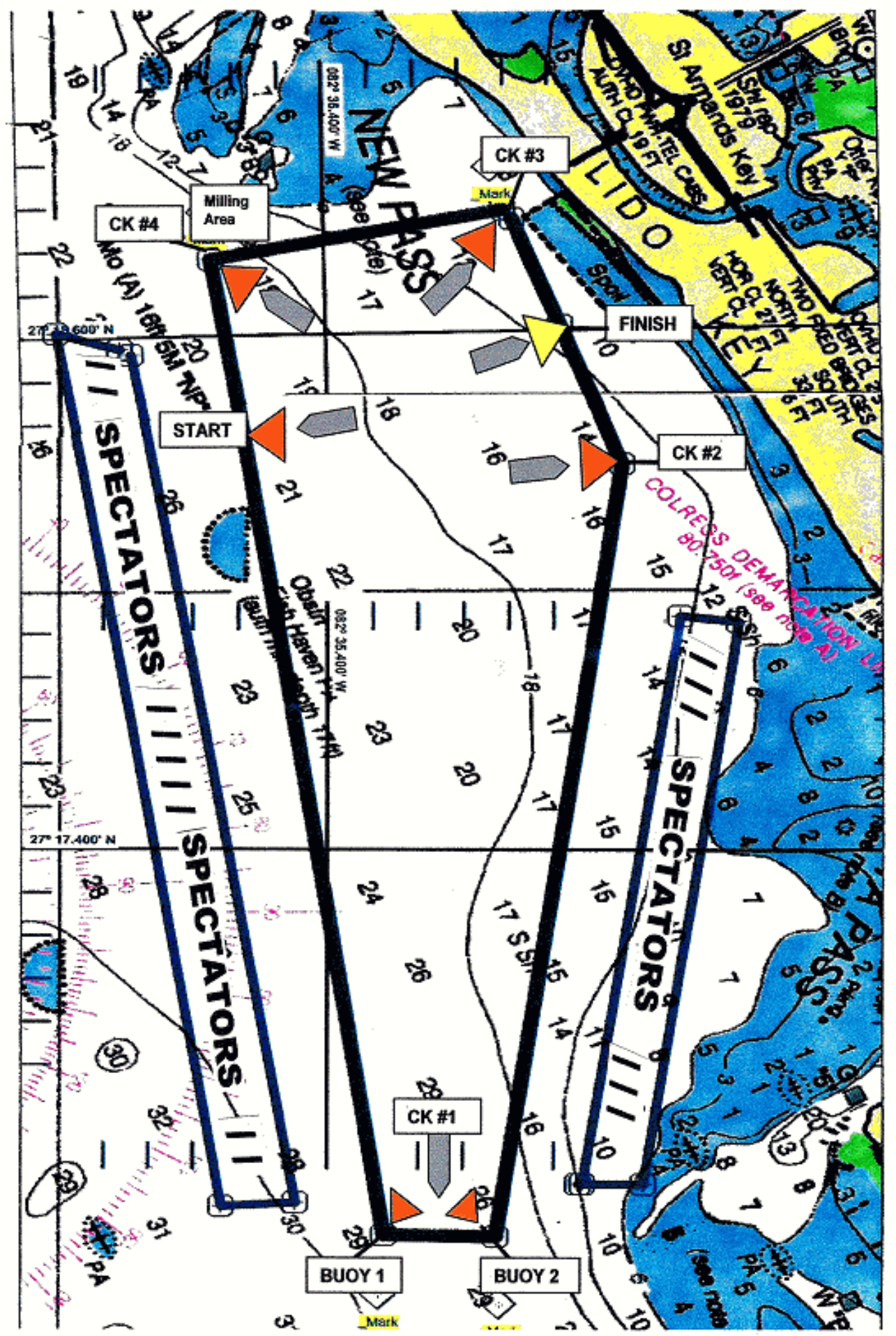

Fig. 11. Office Nautical chart map of the Sarasota Florida Boat Races sponsored by Super Boating International.

Obtained from http://www.suncoastoffshore.org/images/officialmap.gif. 


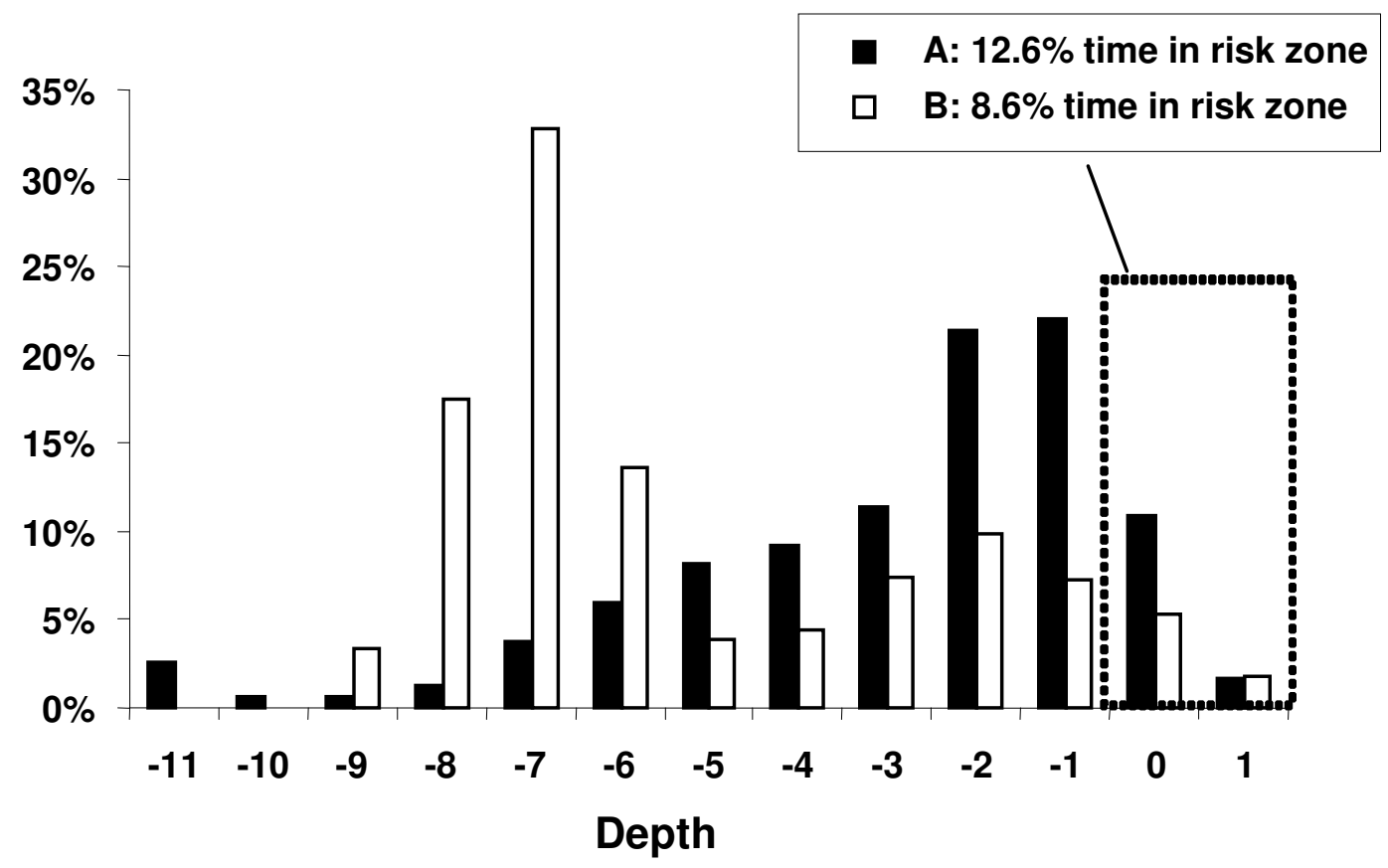

Fig. 12. The depths used by loggerhead females plotted as a percentage of time spent in that depth in the 2007 crittecam study. Turtle A and B are indicated separately as black and white bars respectively.

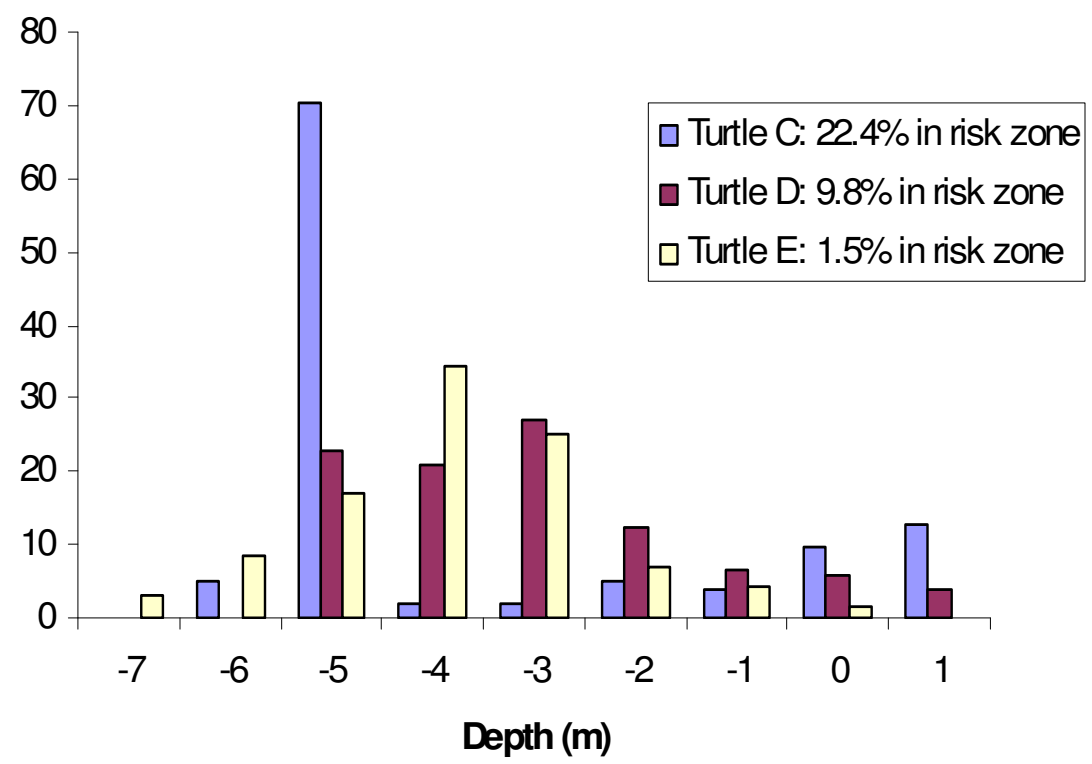

Fig. 13. The depths used by loggerhead females plotted as a percentage of time spent in that depth in the 2008 crittecam study. Turtle C, D, and E are indicated separately as blue, red, and yellow bars respectively. 


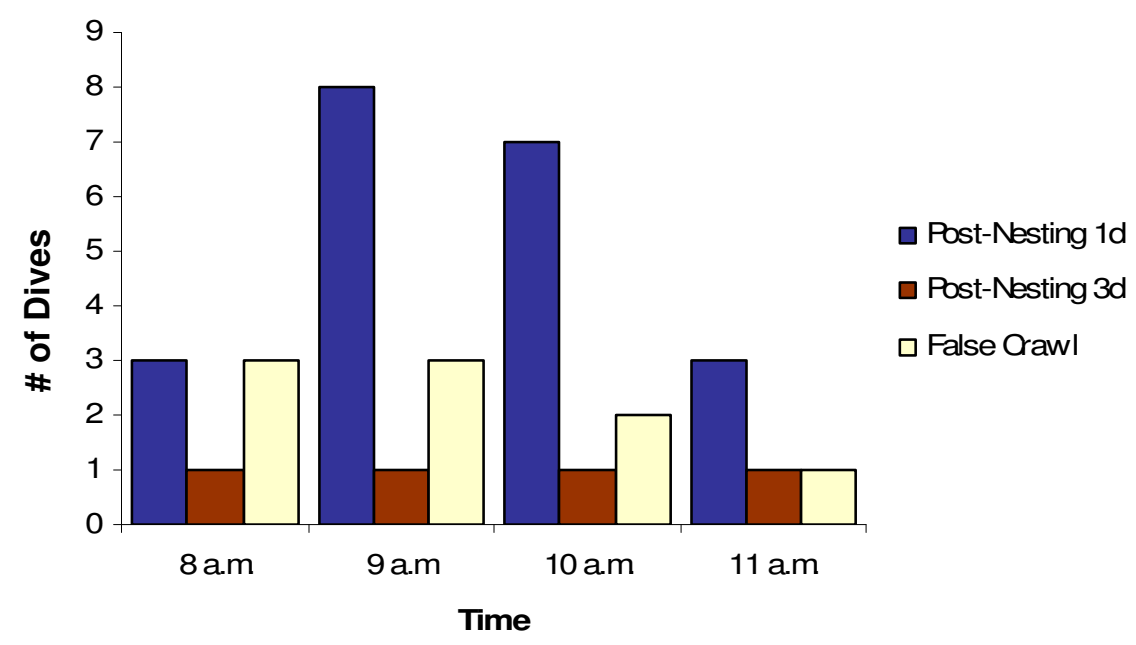

Fig.14. Number of dive an hour is recorded for the 2007 loggerhead turtle. The loggerhead turtle increased the number of dives an hour during the morning hours. Time is in hour segments i.e. 8 a.m. is the period between $8-9$ a.m. $1 \mathrm{~d}=$ first day after nesting, $3 \mathrm{~d}$ $=$ third day after nesting. The second day after nesting was not recorded because the tag was in sleep mode.

\section{Average Number of dives per hour over an 7 day span}

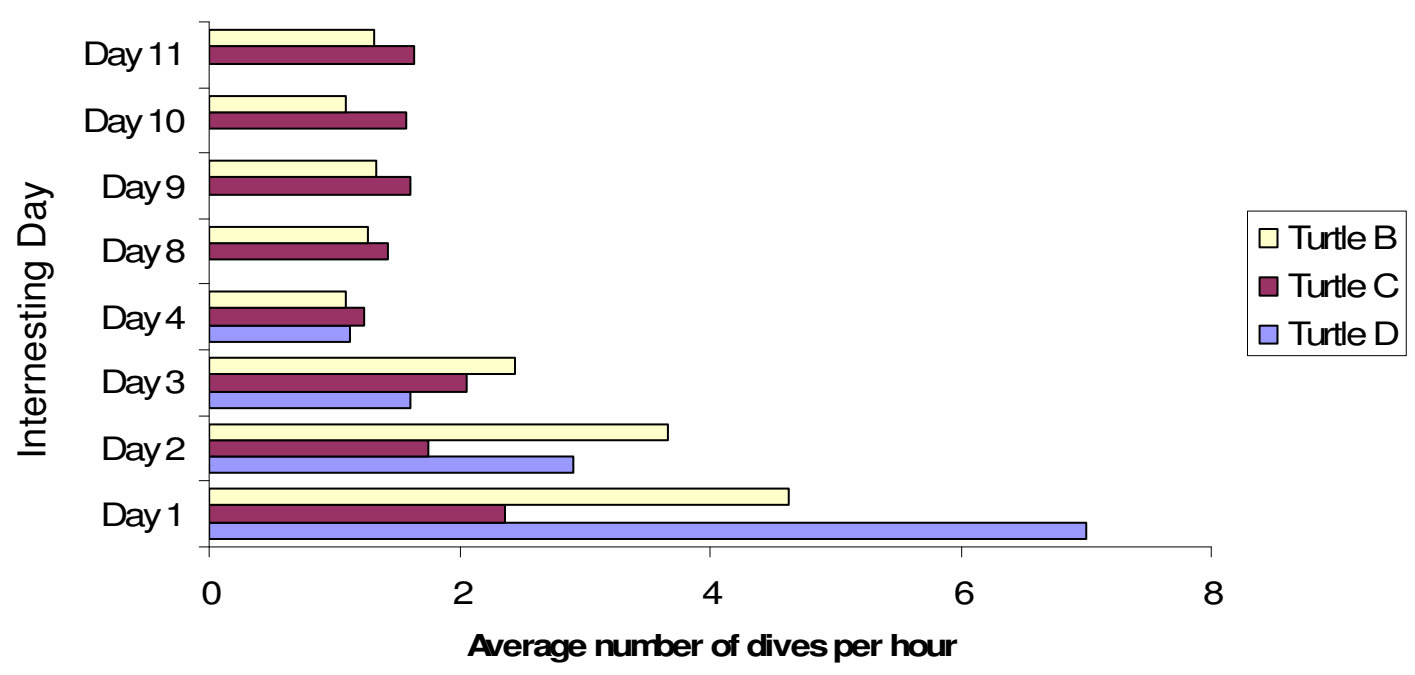

Fig. 15. Average number of dives by day for three internesting turtles in the 2008 dive study. 


\section{Percentage of Time in SRZ}

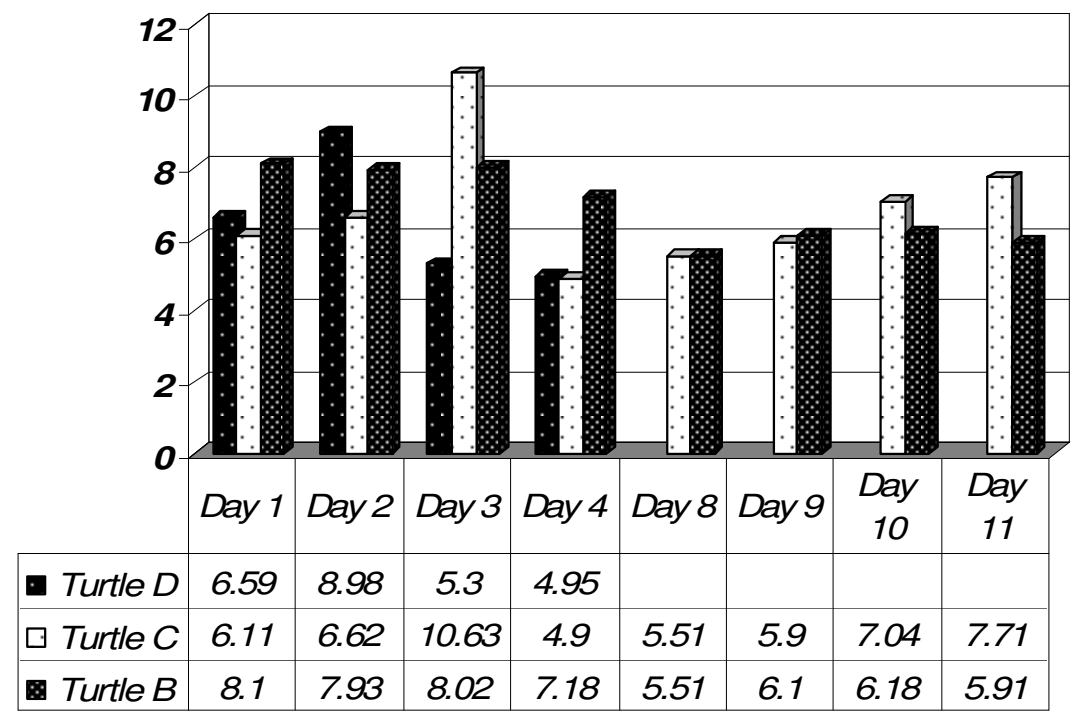

Fig. 16. Percentage of time spent at each depth is represented for three loggerhead turtles in 2008 TDR study.

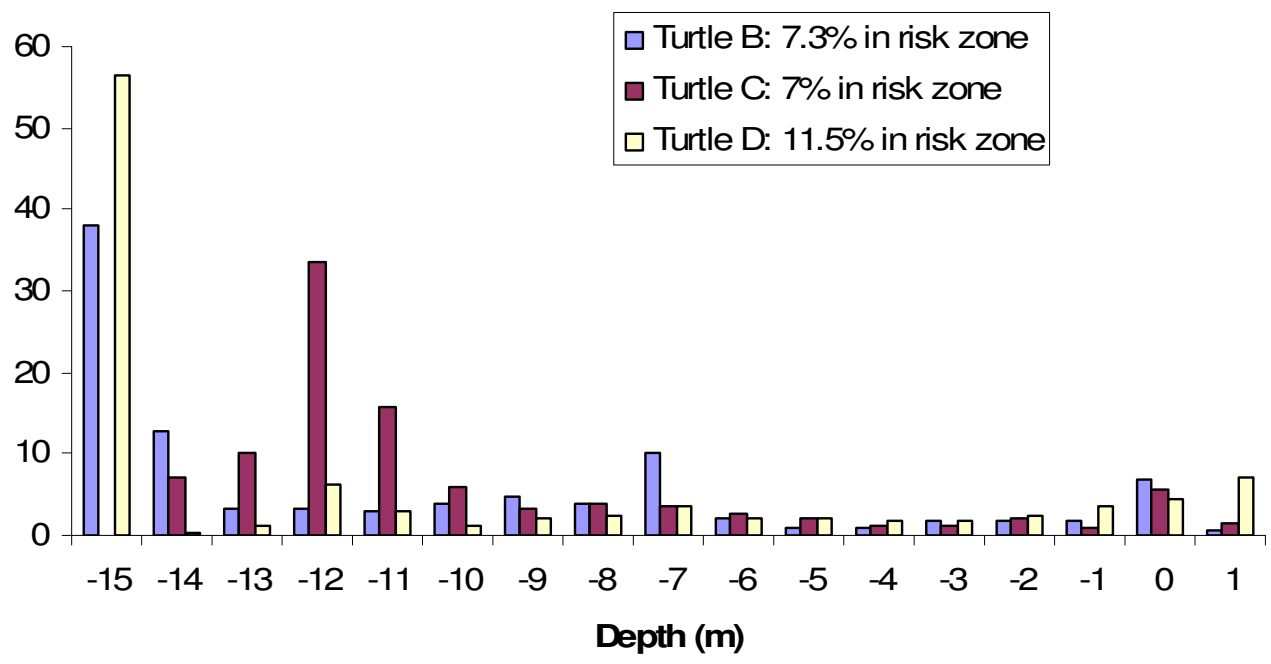

Fig. 17. Percentage of time spent at each depth is represented for three loggerhead turtles in 2008 TDR study. 